
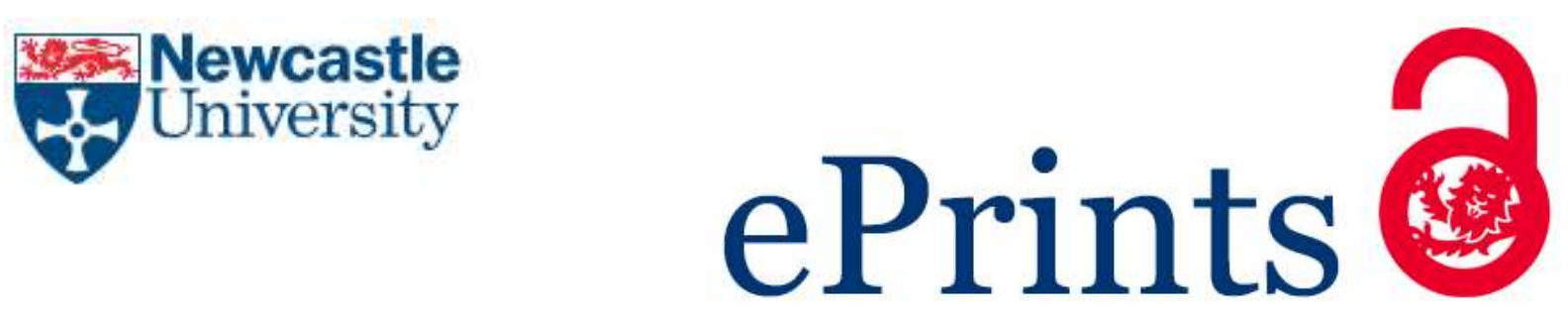

Mohebkhah A, Sarhosis V. Discrete Element Modelling of Masonry-Infilled Frames. In: Sarhosis, V; Bagi, K; Lemos, JV; Milani, G, ed. Computational Modelling of Masonry Structures Using the Discrete Element Method. USA: IGI Global, 2016, pp.146-170.

Copyright:

IGI Global has allowed for this version to be deposited in the repository.

DOI link to article:

http://dx.doi.org/10.4018/978-1-5225-0231-9

Date deposited:

$24 / 06 / 2016$ 


\section{Computational Modeling of Masonry Structures Using the Discrete Element Method}

Vasilis Sarhosis

Newcastle University, UK

Katalin Bagi

Budapest University of Technology and Economics, Hungary

José V. Lemos

National Laboratory for Civil Engineering, Portugal

Gabriele Milani

Technical University in Milan, Italy

A volume in the Advances in Civil and Industrial

Engineering (ACIE) Book Series

HNGINEERING

SCIENCE REFERENCE

An Imprint of IGI Global 
Published in the United States of America by

Engineering Science Reference (an imprint of IGI Global)

701 E. Chocolate Avenue

Hershey PA, USA 17033

Tel: 717-533-8845

Fax: 717-533-8661

E-mail: cust@igi-global.com

Web site: http://www.igi-global.com

Copyright (C) 2016 by IGI Global. All rights reserved. No part of this publication may be reproduced, stored or distributed in any form or by any means, electronic or mechanical, including photocopying, without written permission from the publisher. Product or company names used in this set are for identification purposes only. Inclusion of the names of the products or companies does not indicate a claim of ownership by IGI Global of the trademark or registered trademark.

Library of Congress Cataloging-in-Publication Data

Names: Sarhosis, Vasilis, 1981- editor.

Title: Computational modeling of masonry structures using the discrete element method / Vasilis Sarhosis, Katalin Bagi, J.V. Lemos, and Gabriele Milani, editors.

Description: Hershey PA : Engineering Science Reference, [2016] I Includes bibliographical references and index.

Identifiers: LCCN 2016003307| ISBN 9781522502319 (hardcover) I ISBN 9781522502326 (ebook)

Subjects: LCSH: Masonry--Data processing. I Brickwork--Mathematics. I Stone buildings--Mathematical models. I Discrete element method.

Classification: LCC TH1199 .C678 2016 I DDC 624.1/830113--dc23 LC record available at https://lccn.loc.gov/2016003307

This book is published in the IGI Global book series Advances in Civil and Industrial Engineering (ACIE) (ISSN: 23266139; eISSN: 2326-6155)

British Cataloguing in Publication Data

A Cataloguing in Publication record for this book is available from the British Library.

All work contributed to this book is new, previously-unpublished material. The views expressed in this book are those of the authors, but not necessarily of the publisher.

For electronic access to this publication, please contact: eresources@igi-global.com. 


\title{
Chapter 9 Discrete Element Modeling
of Masonry-Infilled Frames
}

\author{
A. Mohebkhah \\ Malayer University, Iran \\ Vasilis Sarhosis \\ Newcastle University, $U K$
}

\begin{abstract}
In this chapter, the different modeling strategies for simulating the behavior of masonry infilled frames are investigated. Particular emphasis is given on the suitability of the Discrete Element Method (DEM) to accurately represent the mechanical behavior, strength and ductility of concrete and brickwork masonry infilled frames. Within DEM, masonry infill panels are represented by individual bricks and blocks separated by zero thickness interfaces representing mortar joints. The assumptions adopted, the numerical implementation and the advantages and disadvantages of modeling masonry infilled frames using the discrete element method are discussed. This 'discontinuum' approach, an alternative to modeling masonry as a homogenized continuum, is particularly suited for studying the mechanical behavior and interaction between the individual masonry brick/blocks and their interaction with the framed structure.
\end{abstract}

\section{INTRODUCTION}

Building frames are usually infilled with masonry walls. Infilled frames have high in-plane strength and stiffness compared to the corresponding bare frames (no infill). At low levels of lateral forces, the surrounding frame and infill panel behave as a monolithic composite frame. However, as the levels of lateral load increases, an interaction between the surrounding frame and infill panel occurs. The frame behaves in flexural mode and the infill panel deforms in a shear mode. Also, the provision of the infill increases the later stiffness and strength of the frame. However, in current practice the structural effect of infill walls is not taken into account during the analysis of building frames and leads to inaccurate predictions of the building's stiffness, strength and ductility.

Over the last 60 years, extensive numerical and experimental studies have been performed on lateral load behavior of masonry-infilled frames. Experimental and analytical investigations on the lateral stiff-

DOI: $10.4018 / 978-1-5225-0231-9 . c h 009$

Copyright $\odot$ 2016, IGI Global. Copying or distributing in print or electronic forms without written permission of IGI Global is prohibited. 
ness and strength of steel frames infilled with masonry panels have been carried out by Stafford-Smith (1962 and 1966), Mallick and Garg (1971), Riddington and Stafford-Smith (1977), Liauw and Kwan (1985) and Moghadam et al (2006). Also, Dawe and Seah (1989), Mosalam et al. (1997), Schneider et al. (1998), Flanagan and Bennett (1999) and El-Dakhakhni et al. (2002) have studied the behavior of masonry-infilled steel frames under lateral in-plane loads. Saneinejad and Hobbs (1995) developed a method for infilled steel frames inelastic analysis and design subjected to in-plane forces. The model was later adopted by Madan et al. (1997) and implemented in software IDARC for dynamic analysis of infilled frames. A smeared-crack finite element model to study the nonlinear behavior of infilled reinforced concrete frames have been proposed by Mehrabi and Shing (1997). Based on minimizing the factor of safety with reference to the failure surfaces in a masonry infill, Moghadam $(2004,2006)$ proposed a new analytical approach for the evaluation of shear strength and cracking pattern of masonry infill panels.

Stavridis (2009) and Stavridis and Shing (2010) by combining the smeared and discrete crack approaches, proposed a modeling strategy to capture different failure modes of infilled frames. A parametric study has also performed to evaluate the sensitivity of the numerical results to the modeling input parameters. Koutromanos et al. (2011) extended the work of Stavridis and Shing (2010) and used a newly developed cohesive crack interface model and an improved smeared-crack model to capture the cyclic behavior of infilled frames. Recently, Chen and Lui (2015) developed a finite element model adopting the micro-modeling strategy proposed by Dawe and Seah (2001) to study the effect of the size and location of openings on the stiffness and strength of infilled frames.

As an alternative to the finite element-based approaches, a discrete element method (DEM) can be employed to simulate the nonlinear behavior of masonry-infilled steel frames. The DEM was originally used in rock engineering projects where continuity between the separate blocks of rock does not exist (Cundall, 1971). Today, applications of the DEM found application for the understanding of the mechanical behavior of blocky masonry structures (Toth, 2009; Sarhosis et al., 2008; Sarhosis \& Sheng, 2014; Sarhosis, 2015; Giamundo, 2014; Lemos, 1997, 2007; Sarhosis et al., 2014a). Within discrete element method, sliding, large displacements and rotations between blocks, and even the complete detachment of the blocks are allowed with the automatically detection of new contacts as the calculations proceeds. Mohebkhah and Tasnimi (2007) and Mohebkhah et al. (2008) developed a 2D micro-model using the discrete element method to investigate the nonlinear lateral load behavior of confined masonry walls and masonry-infilled frames under monotonic loading. The model was later extended by Sarhosis et al. (2014b) to investigate the influence of the openings on the shear resistance of masonry infilled steel frames. In the following section, a review of the current strategies for modeling masonry-infilled frames will be given with an emphasis on those proposed by the discrete element method.

\section{MECHANICAL BEHAVIOR OF MASONRY-INFILLED FRAMES}

In the early 1950's, for the first time Polyakov (1956) studied experimentally the behavior of masonryinfilled steel and reinforced concrete frames subjected to lateral loads. In order to investigate the effects of parameters such as masonry units, mortar strength, loading type (monotonic or cyclic), panel-to-frame interaction conditions, Polyakov (1956) conducted some large-scale experiments and found that prior to the occurrence of cracks around the perimeter of panel-to-frame interface, the infill panel and the surrounding frame is acting as a monolithic unit. However, as the lateral load increases, the infill panel undergoes some step-wise cracks along the compression diagonal. It was also observed that cracks in 
the masonry infill wall panel pass through mortar head joints and bed joints. Increasing the magnitude of the lateral load, the cracks widened while new cracks appeared until failure of masonry units along the compression diagonal observed. Based on these observations, Polyakov (1956) proposed that masonry-infilled frames can be analyzed as an equivalent braced frame with a compression diagonal strut replacing the infill panel.

Stafford-Smith (1962) conducted some tests on steel frames infilled with concrete masonry blocks. The results showed that the separation between the infill and the frame occurs over three quarters of the length of the surrounding beams and columns. It was also observed that the infill increases the lateral stiffness and strength of the steel frame. Based on further experimental tests and numerical analyses using the finite difference method, Stafford-Smith (1966) proposed the concept of effective width of the infill panel diagonal strut to be used in the analysis of the equivalent braced frame. Later, Mallick and Garg (1971) investigated the effect of openings on the lateral stiffness of infilled frames by testing a series of small-scale steel frames infilled with cement mortar. Mallick and Garg (1971) observed that as the opening position moves towards the compression diagonal, the frame-infill composite action is adversely affected.

Extensive experimental studies conducted at the University of New Brunswick in the early1980's by Dawe to investigate the effect of panel-to-column ties, mortar strength, panel-to-frame friction and bond, gap between roof beam and panel and panel openings on the lateral load behavior of concrete masonry-infilled steel frames. A summary of these studies presented in Dawe and Seah (1989). Dawe and Seah (1989) showed the provision of a gap between the floor beam and panel interface reduces significantly the cracking and ultimate capacity of infilled frames. The study also showed that due to the variable nature of panel-to-frame interface conditions and variable behavior of concrete masonry infill panel, predicting the lateral load capacity of infilled frames is difficult. Comprehensive description of the studies performed until 1987 has been reported in the state-of-the-art report on infilled frames by Moghadam and Dowling (1987).

Mosalam et al. (1997) conducted a quasi-static cyclic experimental program to investigate the behavior of gravity-load designed steel frames infilled with masonry walls. Based on the observed crack patterns, they concluded that the stressed part of the infill (equivalent diagonal strut) has a non-prismatic cross section with large width in the center of the infill panel. Schneider et al. (1998) investigated the in-plane behavior of steel frames with masonry infills having large window openings. Test parameters included the masonry pier width and the number of spans. They found that narrow piers and double span infills tend to be more ductile than wide piers. Flanagan and Bennett (1999) tested some large-scale structural clay tile infilled steel frames under in-plane loading. The results revealed that the failure load of these frames was relatively insensitive to the surrounding frame characteristics. Moghadam (2004) presented the results of an experimental program on retrofitting brick masonry infilled steel frames. El-Dakhakhni et al. (2002) conducted an experimental investigation to study the effect of retrofitting unreinforced concrete masonry-infilled steel frame structures using GFRP laminates. Moghadam et al. (2006) reported the results of an experimental investigation on small and medium scale masonry and concrete infilled frames with and without horizontal reinforcement as well as bond beams under in-plane cyclic loading.

Recently, Tasnimi and Mohebkhah (2011) conducted an experimental program to investigate the in-plane seismic behavior of steel frames with clay brick masonry infills having openings. The experimental results indicate that infill panels with and without openings can improve the seismic performance of steel frames. Also, the amount of cumulative dissipated energy of the infill panels with and without openings at ultimate state is almost identical. Furthermore, the results indicated that infilled frames 
with openings are not always more ductile than the one with solid infill. It appears that, the ductility of such frames depends on the failure mode of infill piers. This experimental investigation showed that the infilled frames with openings experienced pier diagonal tension or toe crushing failure presenting smaller ductility factor than those frames with solid infill.

Markulak et al. (2013) conducted an experimental program to investigate the in-plane cyclic behavior of steel frames with commonly used masonry infills in Croatia. They studied three types of masonry infills: a) perforated clay blocks (C); b) lightweight AAC blocks (A); and c) a newly proposed combination of these materials (CA). They observed that by partial separation of the infill panel from the steel frame at certain drift levels and using the proposed combined masonry infill (CA), it was possible to eliminate the infill's detrimental effects.

Liu and Manesh (2013) tested 14 concrete masonry-infilled steel frames subjected to combined inplane axial and lateral loading. They observed that for the relatively low axial load levels, the presence of axial loading increased the lateral load capacity of the infilled steel frames.

Based on experimental and numerical studies performed in the literature on the behavior of infilled frames, five different in-plane failure modes have been identified for such frames as follows:

1. Corner Crushing (CC): This failure mode can occur in case of rather weak infills as local crushing of masonry units at the ends of diagonal compression struts as shown in Figure 1(a).

2. Horizontal Sliding Shear (HSS): This failure mode can occur in case of very weak infills with very low bed joints shear resistance as a horizontal sliding plane along a bed joint as shown in Figure 1(b).

3. Diagonal Tension Cracking (DTC): This failure mode can occur in case of strong frames with weak connections or weak frames infilled with masonry panels having strong mortar. This failure mode takes place in the form of a step-wise diagonal crack through the bed and head joints or an inclined crack through masonry units as shown in Figure 1(c).

4. Column Flexural Failure (CFF): This failure mode can occur in case of strong frames with weak connections or weak frames infilled with very strong masonry. This failure mode takes place in the form of premature flexural failure of columns or of beam-column connections as shown in Figure $1(\mathrm{~d})$.

5. Column Shear Failure (CSF): This failure mode may occur in infilled reinforced concrete frames' columns after formation of HSS failure mode (Paulay \& Priestley, 1992). In this case, the two masonry sub-panles above and below the horizontal sliding plane in HSS mode would act as two knee bracing members resulting in column shear failure as shown in Figure 1(e).

\section{NUMERICAL MODELING STRATEGIES FOR MASONRY-INFILLED FRAMES}

The abovementioned literature review on the behavior of masonry infilled frames reveals that simulation of masonry-infilled frames is one of the most complicated problems in structural engineering field. This is due to the fact that an infilled frame is a composite frame comprising of two interacting components of different material (e.g. the surrounding frame and masonry infill panel) with different structural behavior and failure mechanisms. Masonry infill panel itself is a heterogeneous material with different failure modes and complicated behavior depending on its constituent elements' characteristics and the applied loads intensity and type. This complexity is mainly attributed to the discontinuum nature of 
Figure 1. In-plane failure modes of infilled frames: (a) corner crushing mode; (b) horizontal sliding shear mode; (c) diagonal tension cracking model; $(d)$ column flexural failure mode (El-Dakhakhni et al., 2003); and (e) column shear failure mode (Paulay \& Priestley, 1992)

$P$

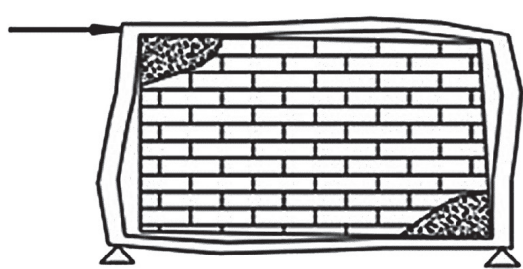

(a) CC mode

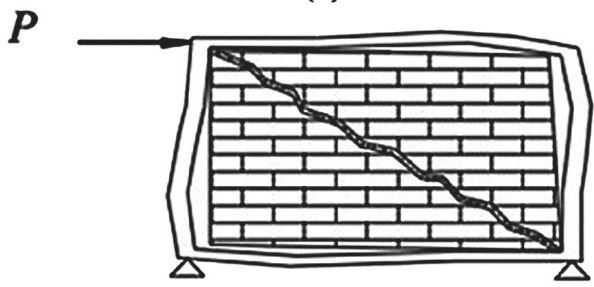

(c) DTC mode

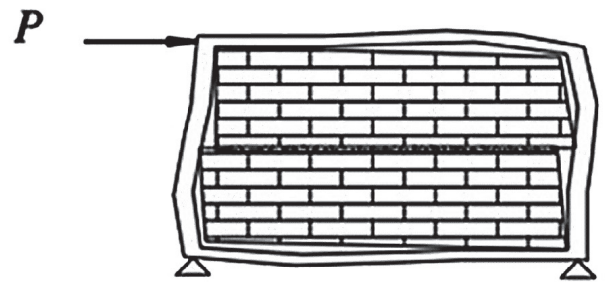

(b) HSS mode
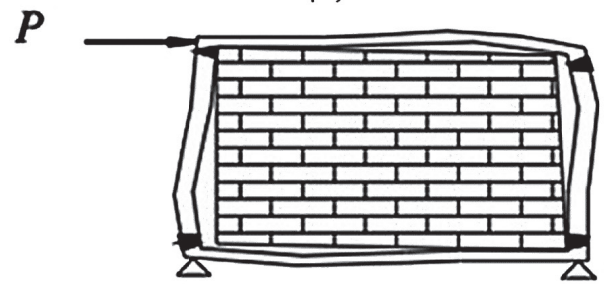

(d) $C F F$ mode

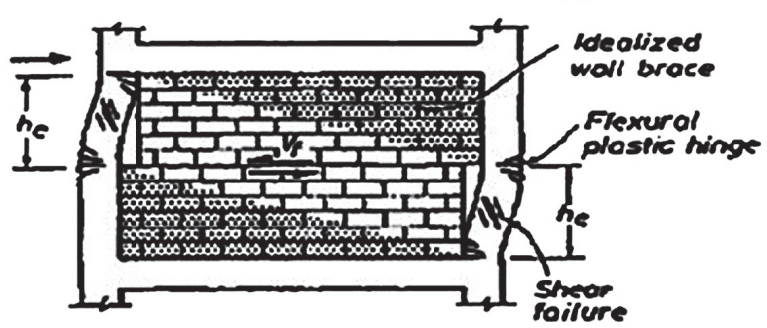

(e) CSF mode

masonry panel and the existence of joints between masonry units as the major source of weakness and material nonlinearities. Another important factor that increases the complexity of infilled frames' behavior simulation is the interaction between the infill-to-frame. The infill-to-frame interaction depends on infill-frame relative stiffness, infill-frame friction and bond as well as gap between roof beam and panel. Therefore, a suitable numerical modeling strategy for the $2 \mathrm{D}$ analysis of infilled frames is to be capable of simulating the following phenomena:

1. Mortar joints sliding and opening.

2. Compressive and shear failure of masonry units (blocks).

3. Block-mortar or block-block interaction.

4. Infill-frame interaction.

Numerical modeling strategies of infilled frames are divided into two distinct categories (see Figure 2). These are: a) macro-modeling; and b) micro-modeling.

In macro-modeling strategy for modelling the mechanical behavior of masonry-infilled frames, the solid masonry infill panel is replaced by an equivalent system. The simplest model in this category was 
Figure 2. Micro-modeling strategies for masonry walls: (a) detailed; and (b) simplified (Lourenco 1996)

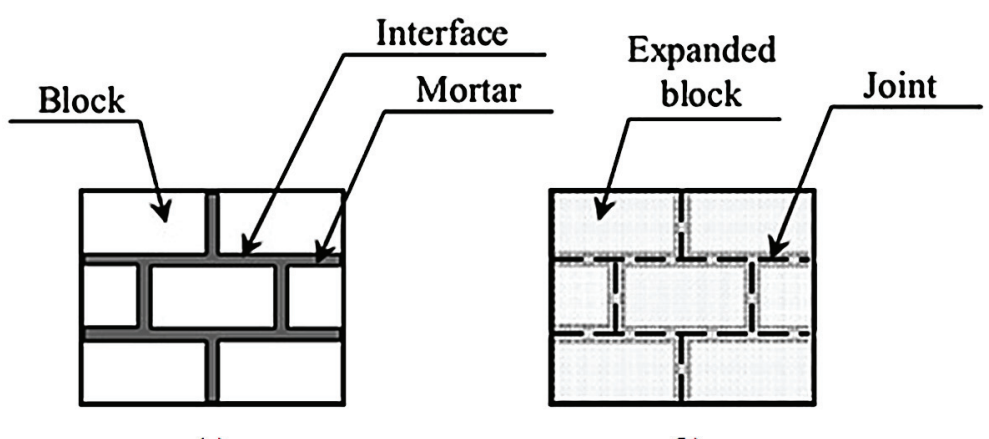

(a)

(b)

proposed by Stafford-Smith (1966) and then adopted and developed by Mainstone (1971). According to this model, an equivalent pin-jointed diagonal strut is substituted for the infill panel. In the literature, a number of macro-models have been proposed by several researchers. Among them, the models proposed by Chrysostomou et al. (2002), Mosalam et al. (1997a, 1998), Saneinejad and Hobbs (1995), and ElDakhakhni et al. (2003) are distinguished. In the model suggested by Chrysostomou et al. (2003), the infill is idealized with three compression only inclined struts in each direction, which follow the behavior defined by the strength envelope and hysteretic loop equations. The off-diagonal struts are located to represent the interaction between the infill and confining steel frame. Mosalam et al. (1998) proposed a macro-model in which the infill panel is represented by an equivalent nonlinear truss with contact and tie (tension) elements. Saneinejad and Hobbs (1995) developed an inelastic analysis and design method for infilled steel frames subjected to in-plane forces. This method was later adopted and implemented in software IDARC for dynamic analysis of such frames by Madan et al. (1997). El-Dakhakhni et al. (2003) adopting the analysis methodology and concept of Saneinejad and Hobbs' model (1995), proposed a simple nonlinear macro-model to estimate the stiffness and the lateral load capacity of solid masonry-infilled steel frames failing in corner crushing (CC) mode. In this method, each masonry panel is replaced by three struts (one diagonal and two off-diagonal) with nonlinear force-deformation characteristics. The abovementioned macro-models are capable of predicting the global behavior of infilled frames failing in CC mode. However, these models cannot capture most of the other complicated failure modes and local effects of infill-frame interaction mentioned in Sec. 2 and Figure 1.

In micro-modeling strategy for modeling the mechanical behavior of masonry-infilled frames, both the surrounding frame and the infill panel components details (i.e. masonry units and mortar joints) can be simulated using a numerical method such as finite element method or discrete element method. In this strategy, the interaction between masonry units and mortar along the joints as well as the frame-infill interaction is taken into account ("detailed micro-modeling method"). There is also a "simplified micromodeling method" in which each joint is modeled as an interface with zero thickness. In this method, fictitious expanded block dimensions are used that are of the same size as the original dimensions plus the real joint thickness as shown in Figure 2(b). The interface's stiffness is represented numerically by the stiffness of the real joint. The inelastic, isotropic model is used for the behavior of the blocks. The blocks can be considered rigid or fully deformable; thus allowing deformation to occur both in the blocks and joints and a better simulation of blocks crushing, crack propagation and sliding in the joints. Deformable blocks are internally discretized into Finite Difference triangular zones and each element 
responds according to a prescribed linear or non-linear stress-strain law. These zones are continuum elements as they occur in the Finite Element Method (FEM). Mortar joints between masonry blocks can be viewed as the interfaces representing interactions between the blocks. These are simulated employing the appropriate stress-displacement constitutive laws. The interaction between the blocks is represented either by a set of "point" contacts or by a set of "edge-to-edge" contacts (without any attempt to obtain a continuous stress distribution through the contact surface). Also, failure in the masonry block can be simulated by introducing interface elements (or otherwise fictitious crack patters) within the block. Such interface will have the characteristics of the bock. From the above, it can be seen that micro-models are capable of predicting both global and local behavior of infilled frames failing in different in-plane modes introduced in Sec. 2 and Figure 1.

Achyutha et al. (1986) developed a two dimensional elastic finite element model to investigate the effect of size of opening and types of stiffeners on the lateral stiffness of infilled frames with openings. Mehrabi and Shing (1997) have proposed a smeared-crack nonlinear finite element model to study the nonlinear behavior of infilled reinforced concrete frames. Simplified modeling strategies have also been investigated using finite element method by Mosalam (1997), Dawe et al. (2001), Ghosh and Amde (2002), Asteris (2003), Mohebkhah (2007), Mohebkhah et al. (2008), Stavridis (2009), Stavridis and Shing (2010), Koutromanos (2011), Koutromanos et al. (2011) and Sarhosis et al. (2014b). Extensive reviews on numerical micro-modeling aspects of masonry-infilled frames and masonry structures have been presented in Asteris et al. (2013) and Asteris et al. (2015).

\section{DISCRETE/DISTINCT ELEMENT METHOD}

Discrete/distinct element methods (DEMs) were originally developed for the study of jointed and fractured rocks due to the capability of the method to explicitly represent the motion of multiple, intersecting discontinuities and fractures (Sharma et al. 1999). More recently, discrete element methods have been used for the analysis of the masonry structures in which a significant part of the deformation is due to relative motion between the blocks and cracking tends to be along the brick/mortar interfaces and failure usually results from de-bonding of the bricks. So far, various discrete element applications to masonry shear walls (Mohebkhah \& Tasnimi, 2007; Sarhosis \& Sheng, 2014), unreinforced masonry buildings (Sincraian \& Azevedo, 1998; Mohebkhah \& Sarv-Cheragi, 2015), stone masonry arches (Toth et al., 2009), ancient structures (Sincraian et al., 1998; Azevedo et al., 2000; Psycharis et al., 2000; Psycharis et al., 2003; Giordano et al., 2002), and dry-stone retaining walls (Claxton et al.; 2005) have been reported for both static and dynamic analysis in the literature. Mohebkhah et al. (2008) developed a 2D distinct/ discrete element model using the Universal Discrete Element Software UDEC (Itasca, 2004) for the inelastic analysis of concrete masonry-infilled steel frames which considers both geometric and material nonlinearities. The Universal Distinct Element Code (UDEC) is a two-dimensional numerical program based on the distinct element method for discontinuum modeling (Cundall, 1971). UDEC simulates the response of discontinuous media subjected to either static or dynamic loading. The discontinuous medium is represented as an assemblage of discrete blocks. In DEM, the discontinuities are treated as boundary conditions between blocks in which large displacements along discontinuities and rotations of blocks are allowed. In other words, the joints are viewed as interfaces between distinct bodies. Therefore, the starting point of a discrete element model is a discontinuous system, in contrast with the FE method, which evolved from the representation of a continuum media (Lemos, 2007). 
Individual blocks can be represented as either rigid or deformable material. Rigid blocks when masonry units are subjected to low intensity stresses and the deformations in them are relatively small compared to their total strength. Alternatively, masonry unit blocks can be considered as deformable. Deformable blocks are subdivided into a mesh of finite-difference triangular elements, where each element responds according to a prescribed linear or nonlinear stress-strain law. The formulation of these elements is similar to the constant strain triangle (CST) finite element formulation. The complexity of the deformation of the bricks depends on the number of zone elements into which they are divided. Zones obey to the constitutive model assigned to them and, for each separate block the strain can be estimated. In UDEC, the deformable block zones can be assumed to be linear elastic or non-linear according to the Mohr-Coulomb criterion (Itasca, 2004a). The disadvantage of this element is that, in case of complicated deformation problems such as beam-to-column behavior in an infilled frame, the number of triangular elements in which the area has to be discretized may become very large.

Mechanical interaction between blocks is considered by normal and shear elastic springs connected at the blocks. The relative motion of the discontinuities is also governed by linear or nonlinear (as appropriate) force-displacement relations for movement in both the normal and transverse (tangential) directions. The formulation used in the program permits both geometric and physical non-linearities of the intact material to be modeled. UDEC has several built-in material behavior models (i.e. linear elastic, Mohr-Coulomb, Mohr-Coulomb with residual strength, etc.), for both intact blocks and the discontinuities, which permit the simulation of response representative of discontinuous materials. The program uses "Lagrangian" calculation scheme that is well-suited to model the large movements and deformations of a blocky system (Itasca, 2004). In this program, the explicit solution procedure is used, in which motion equations are set up for each time increment. This takes place for each block sequentially. The behaviour of the masonry is based on the knowledge of the properties of each constituent and the interface. Material properties are normally obtained from experimental tests on the masonry units, the mortar and on masonry samples.

The original UDEC program was based on the plane strain situation. In the UDEC 4.0 version it is possible to give the stress perpendicular to the plane of the structure a constant value. The plane stress situation is then obtained by giving the stress perpendicular to the plane of the structure a value of zero. This is encountered, for example, in masonry structures loaded only in the plane of the structure.

The calculations performed in the discrete element method alternate between the application of a force-displacement law at all contacts and Newton's second law at all blocks or nodes (Itasca, 2004). The force-displacement law is used to find contact forces from known displacements. Newton's second law gives the motion of the blocks resulting from the known forces acting on them. Figure 3 demonstrates the calculation cycle for the distinct element method (Itasca, 2004). Mechanical damping is used in the DEM to solve both static and dynamic solutions. For each case, a different type of damping is used. For static analysis, an approach similar to dynamic relaxation technique is employed and the equations of motion are damped to reach the equilibrium state.

Discontinuous deformation analysis (DDA) is an alternative method for the analysis of jointed and blocky systems. The method proposed by Shi and Goodman (1988). DDA is an implicit discrete element method for the analysis of jointed rock mass problems. To determine the variables in DDA (i.e. the displacements), the equations of equilibrium are solved similar to the finite element method. On the contrary to the distinct element method where a "soft contact" approach is used and blocks can overlap when they are in compression, contacts in DDA are considered to be rigid (the "hard contact approach"). The main differences between the DEM and DDA have been given in Bićanić et al. (2001); 
Figure 3. Calculation cycle for the discrete element method (Itasca, 2004)

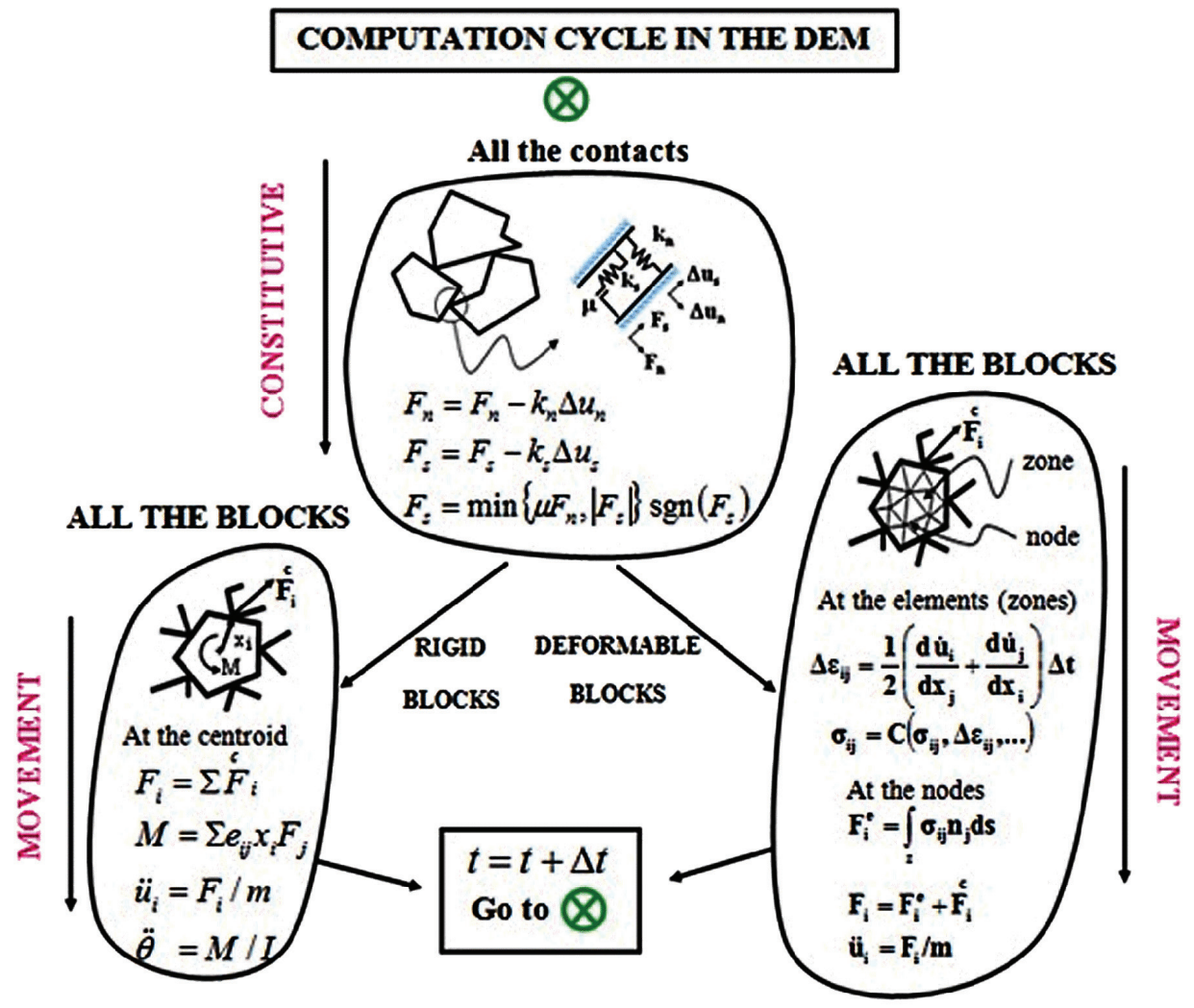

Bobet et al. (2009); and Lisjak and Grasselli (2014). DDA has two advantages over the DEM. These are: a) permission for relatively larger time steps; and b) closed-form integrations for the stiffness matrices of elements (Jing, 2003).

There are numerous simplified micro-modeling strategies in the literature which can be utilized using the FEM for the analysis of masonry-infilled frames. However, these procedures generally fail to simulate the response of infilled frames when large displacements and rotations between masonry units or complete detachment of the units occur. Nevertheless, there are some advanced discontinuum finite element programs such as DIANA (developed by Lourenco, 1996) that include interface elements allowing the user to analyze properly masonry panels with large displacements and rotations between their constituents. As an alternative, the DEM as pointed out in previously has the capability of simulating all failure modes of masonry-infilled frames even complete and large detachment of masonry units. The DEM also has the capability of detecting new contact points as the analysis proceeds.

\section{PROCEDURE USED FOR MODELLING MASONRY INFILL WALL PANELS}

The procedure used to model masonry structures using the discrete element method is discussed in more detail below. This methodology is based on the authors' personal experience of using UDEC. 
Step 1: Understand the objectives of the model analysis.

The objectives of the analysis are important in determining the level of the detail to be included in a model. Often, it is not necessary to produce a complex model with excessive details just because it is like that in reality. Complicated features should be omitted if they are likely to have little influence or they are irrelevant to the purpose of modelling. A simple model should be built first for the feasibility study and validation purposes and later refinements can be added as (and if) necessary. For example, it is usually more appropriate to model plain masonry first and then add elements such as reinforcement.

Step 2: Create a conceptual picture of the physical system.

It is very important to have a conceptual picture of the problem in order to provide an initial estimate of the physical characteristics of the system. The modeller should decide upon the suitability and applicability of the model's geometry, constitutive laws, the boundary conditions and the initial equilibrium state.

Step 3: Generate the model.

After deciding upon the objectives of the modelling analysis and the physical characteristics of the system, it is time to generate the initial model. The first task involves the generation of the model's geometry. The model should begin with a single block which spans the physical region being analysed. By cutting this block into smaller blocks, the detailed features (i.e. mortar joints, windows/doors openings etc.) are introduced. Also, a choice between rigid or deformable blocks should be made by the modeller. Next, the material behaviour and properties should be assigned. The constitutive behaviour and the associated material properties will dictate the response of the model to external loading. As described previously, the user has a number of choices for the constitutive model that can be used in the analysis. Also, material properties can be obtained from the literature or from testing. The boundary and initial conditions that represent the in-situ state (i.e. the condition before a change or disturbance such as external loading is introduced) are then defined. Finally, if required by the user, structural members such as reinforcement can also be included.

Step 4: Bring the model into equilibrium.

The next step is to bring the model into a state of equilibrium otherwise alternations cannot be performed. At this state only the initial boundary conditions, including the self weight effects, are applied to the model. As UDEC uses an explicit solution process, the solution is reached after a series of computational steps. The user is required to specify a number of calculation steps to bring the model into a state of equilibrium. According to Itasca (2004), the model is in equilibrium only when "the net nodal vector at each grid point of deformable block is zero". However, for a numerical analysis, the out of balance force will never reach exactly zero. In practice, it is assumed that the model is in equilibrium only when the maximum unbalanced force is relatively small compared to the force applied to the model (i.e. a difference of less than $1 \%$ ). The force imbalance in the model is caused by the slight difference in the location of contact forces and grid point forces at block corners (Itasca, 2004a \& b). This is related to corner rounding (Section 3.3). 
Step 5: Perform alterations.

Once the model is in equilibrium, alterations such as external loading and thermal changes can be applied and new structural elements (such as reinforcement) can be introduced.

Step 6: Step to solution.

UDEC uses an explicit time-machine method to solve the algebraic equations, described earlier in Section 3.4. A solution is reached after a series of computational steps have been executed. The number of steps is controlled manually by the user who must determine if the number of steps is sufficient to reach the solved state required.

Step 7: Examine model response.

When modelling masonry in order to assess the failure load, it is recommended that loading is applied monotonically to the model until failure occurs. According to Itasca (2004), in order to determine a collapse load, it is often appropriate to use "strain-controlled" boundary conditions rather than "stresscontrolled" - i.e., a constant velocity is applied and the boundary reaction forces are measured rather than applying forces and measuring displacements. According to Itasca (2004), "a system that collapses becomes difficult to control as the applied load approaches the collapse load". Collapse can occur when the system is incapable of carrying any more load; this condition is judged by the user rather than being identified by the software. The model's response can be examined against theoretical/analytical methods of analysis or from similar laboratory tests.

Step 8: Present results for interpretation.

The final stage of problem solving involves the presentation of the results for a clear interpretation and analysis. In UDEC the results can be presented graphically either electronically or as a hard copy for easy comparison with field or laboratory measurements and observations. Various results can be generated by the software including: block velocity; displacements; forces; grid point stresses and strains; and contact detachment/crack patterns. In addition, history plots of load against displacement, crack widths and crack lengths at each time step of the analysis can be obtained. History plots are especially helpful to monitor whether a state of equilibrium or failure has been reached.

\section{DEM MODELING ASPECTS OF MASONRY-INFILLED STEEL FRAMES}

For the analysis of the nonlinear lateral load behavior of masonry-infilled steel frames using a simplified DEM micro-modeling method, simulations should be carried out sequentially. First each model is brought to equilibrium under its own dead weight and then external load is applied to it. In order to determine a collapse load and simulate the post-peak behavior of masonry-infilled steel frames, it is often better to use displacement-controlled boundary conditions rather than force-controlled. Therefore, incremental horizontal displacement is usually applied to each model/domain to be studied. 


\section{Elastic Parameters}

As pointed out earlier, individual masonry units can be modeled as either rigid or deformable material. To capture the linear-elastic behavior of masonry units, a linear-elastic constitutive model is sufficient. In this case, deformable units are subdivided automatically into a mesh of triangular elements in which each element responds according to a prescribed linear or nonlinear stress-strain law as it will be discussed later in Sec. 5.2. To define the constitutive model of interface joints, the following stress-displacement relationship between the interface stress vector $\mathbf{t}$ and the interface displacement vector $\delta$ is adopted:

$\mathbf{t}=\mathbf{K}^{\prime}$

in which

$$
\mathbf{t}=\left\{\begin{array}{l}
\sigma \\
\tau
\end{array}\right\}, \quad \delta=\left\{\begin{array}{l}
u \\
v
\end{array}\right\}, \quad \mathbf{K}=\left[\begin{array}{cc}
k_{n} & 0 \\
0 & k_{s}
\end{array}\right]
$$

and $\mathrm{k}_{\mathrm{n}}$ and $\mathrm{k}_{\mathrm{s}}$ are the joint normal and shear stiffnesses, respectively. In order to generate a simplified DEM micro-model based on interface elements with zero thickness, the size of the blocks has to be expanded by the mortar thickness $\left(h_{m}\right)$ in both directions. It follows that the elastic properties of the "expanded" block and the "interface" joint must be adjusted to yield correct results. Contact points in UDEC are assumed to be "soft". This means that contact forces are generated as a result of interpenetration of adjacent blocks at their contacts. The joint stiffness parameters $\left(\mathrm{k}_{\mathrm{n}}\right.$ and $\left.\mathrm{k}_{\mathrm{s}}\right)$ describe the stress deformation characteristics of the joints. According to Itasca (2004), the joint stiffnesses do not represent actual masonry parameters but they are mathematical values required by the 'soft' contact model used in UDEC which control the interpenetration of adjacent blocks in the model. For example, if the block stiffnesses are high then small amounts of interpenetration will occur. The amount of interpenetration is controlled by the user and does not influence the calculation time. Also, due to the zero thickness of the interfaces, the geometry of the bricks has to be expanded to incorporate the thickness of the joint in both directions. Due to the relative dimensions of mortar and block, it is assumed that the elastic properties of the blocks remain unchanged. Then, under the assumption of stack bond and uniform stress distributions both in the block and mortar as shown in Figure 4, the following relation can be written between the equivalent axial stiffness of the real (detailed) and the simplified situations, which is a function of the Young's Modulus and thickness of the joint:

$\sum\left(\frac{1}{k_{i}}\right)_{\text {det ailed }}=\sum\left(\frac{1}{k_{i}}\right)_{\text {simplified }}$

then

$\frac{h_{b}}{E_{b}}+\frac{h_{m}}{E_{m}}=\frac{h_{b}+h_{m}}{E_{b}}+\frac{1}{k_{n}}$ 
Figure 4. Scheme to determine joint normal stiffness: (a) real masonry prism; (b) expanded block with zero-thickness interface element (springs in series analogy)

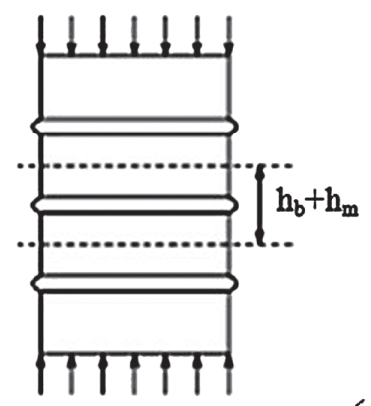

(a)
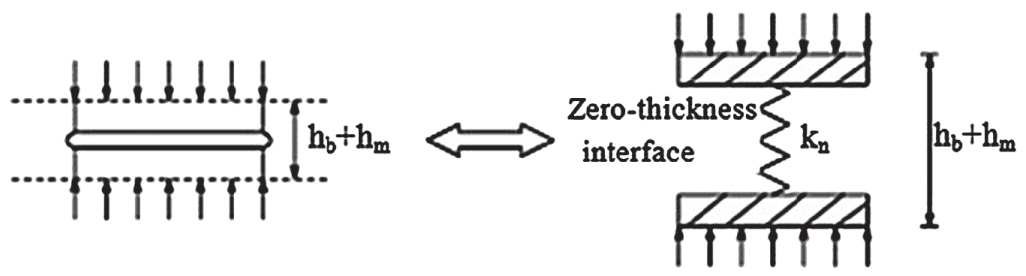

(b)

or

$k_{n}=\frac{E_{b} E_{m}}{h_{m}\left(E_{b}-E_{m}\right)}$

$\mathrm{k}_{\mathrm{n}}$ is the stiffness of the equivalent spring as shown in Figure 4(b). A similar expression can be derived for joint shear stiffness as follows:

$k_{s}=\frac{G_{b} G_{m}}{h_{m}\left(G_{b}-G_{m}\right)}$

In the above relations, $h_{b}=$ height of the block; $E_{b}$ and $E_{m}$ are the Young's modulus, $G_{b}$ and $G_{m}$ are the shear modulus, respectively, for block and mortar. For the analysis of dry joint stone masonry walls using the simplified micro-modeling method, Lourenco et al. (2005) proposed the following expressions to determine the joint normal and shear stiffnesses:

$$
\begin{aligned}
& k_{n}=\frac{1}{h_{s}\left(\frac{1}{E_{\text {wall }}}-\frac{1}{E_{\text {stone }}}\right)} \\
& k_{s}=\frac{k_{n}}{2(1+\nu)}
\end{aligned}
$$

where $h_{s}=$ height of the stone unit; $\nu=$ Poisson's ratio of wall; and $E_{\text {wall }}$ and $E_{\text {stone }}$ are the Young's modulus of the wall and the stone unit, respectively. Using advanced detailed discontinuum finite element analyses, the accuracy of simplified micro-modeling strategy has been verified by Lourenco (1996). 
Apart from the aforementioned spring elements to connect masonry units to each other and the infill panel boundary nodes to the surrounding frame, there are various infill-frame interface elements in the literature (King \& Pandey, 1978; Dhanasekar \& Page, 1986; Mosalam et al., 1997; Dawe et al., 2001). Also, Koutromanos (2011) and Koutromanos et al. (2011) extended the work in Stavridis and Shing (2010) by using a combined discrete and smeared crack approach to investigate the behavior of masonry-infilled, non-ductile RC frames subjected to lateral cyclic, static and earthquake loads. The main novelty in this research is the use of a newly developed cohesive crack interface model and an improved smeared-crack model to capture the cyclic behavior of such structures.

\section{INELASTIC PARAMETERS AND CONSTITUTIVE CRITERIA}

\section{Infill Panel Material}

A characteristic feature of UDEC is the geometric non-linearity of the intact bricks/blocks to be modelled. The displacement of the bricks due to shear and opening up of the interfaces can be immediately included in the calculations. So, it is possible that masonry units which were originally adjacent to each other to become partially or entirely detached from each other, or new contact points to be formed. This is significant feature of UDEC software when modelling problems involving discontinuities such as low bond strength masonry, where the predominant failure mechanism is due to the de-bonding of the bricks or blocks from the mortar, as the location and the magnitude of surface crack widths within a masonry structure can be determined realistically. Detecting and updating brick/block contacts is the most time consuming part of the software's calculation.

There are many parameters that affect the behavior of the model. The most fundamental parameter is the constitutive model chosen to represent the material behavior. UDEC version 4.0 has some built-in constitutive material models such as: isotropic elastic, Drucker-Prager, Mohr-Coulomb and strainhardening/softening. In the case of very low stress levels, a linear-elastic model is sufficient. However, for high stress levels a nonlinear model which can simulate crack formation, shear or crushing is needed. The nonlinear post-peak behavior of stone-like materials such as masonry is characterized by softening which determines the way in which crack formation propagates within a block (Rots, 1997). It has been shown that when the shear displacement increases, the masonry block cohesion does not suddenly, but more or less gradually decreases to zero (Rots, 1997). This quasi-brittle behavior (known as softening) has been observed in tension, compression and shear. This softening behavior in masonry units is attributed to the gradual break down of the weakest links followed by formation of micro-cracks and finally linking up the cracks to form a macro-crack or shear plane (Rots, 1997). Hence, masonry units softening behavior (e.g. concrete blocks or clay bricks) is possible to be simulated using a strain-hardening/softening material model such as UDEC Mohr-Coulomb model with tension cut-off in conjunction with non-associated shear and associated tension flow rules. The difference, however, lies in the possibility that the cohesion, friction, dilation and tensile strength may harden or soften after the onset of plastic yield. In the Mohr-Coulomb model those properties are assumed to remain constant (Itasca 2004). However, in the strain-hardening/softening material model, the user can define the cohesion, friction and dilation as piecewise-linear functions of a hardening parameter measuring the plastic shear strain. In other words, the post-failure behavior in a strain-softening model is dictated by values for angle of internal friction and cohesion, which decrease with increasing percent strain after failure. Cohesive 
strength of masonry units can be calculated using uniaxial and triaxial tests. However, as an approximation, cohesion strength of units can be estimated based on their internal friction angle $(\varphi)$ and compressive strength $\left(f_{b}^{\prime}\right)$. To this end, utilizing the Mohr-Coulomb model as shown in Figure 5(a), the following relation is derived:

$$
c=\frac{f_{b}^{\prime}}{2 \operatorname{Tan}\left(45+\frac{\varphi}{2}\right)}=\frac{f_{b}^{\prime}}{2}\left(\frac{1-\sin \varphi}{\cos \varphi}\right)
$$

Strain-softening model for the blocks is described by two parameters. These are the cohesion (c) and the angle of internal friction $(\varphi)$. The angle of internal friction and cohesive strength of masonry blocks can be calculated based on uniaxial and triaxial tests which are performed on representative sample blocks. For the case of concrete-masonry infills, the angle of internal friction and cohesive strength of blocks/units can be calculated using the relations given by Tasnimi and Farzin (2006). They developed a 3D finite-element model for nonlinear analysis of plain concrete columns. The model was validated with the results of some experimental tests. Then, the FEM model was used for a parametric study to obtain two relations for the angle of internal friction and cohesion of concrete in terms of concrete compressive strength $\left(f_{c}^{\prime}\right)$. In the parametric study, bearing capacity of a plain concrete column varying

Figure 5. (a) Mohr-Coulomb failure model with tension cut-off, (b) tension strength softening; and (c) cohesion strength softening

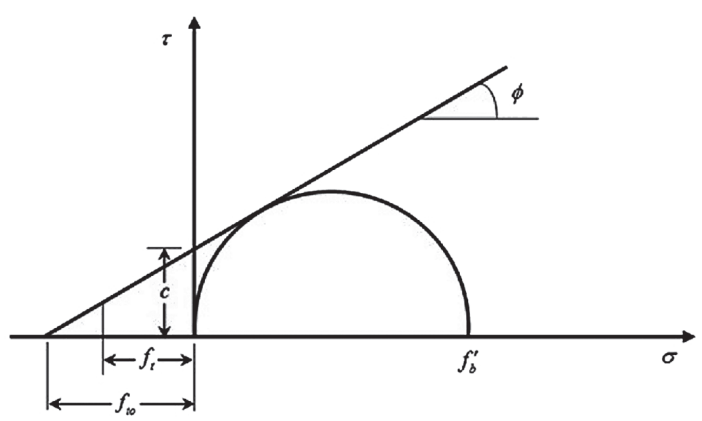

(a)

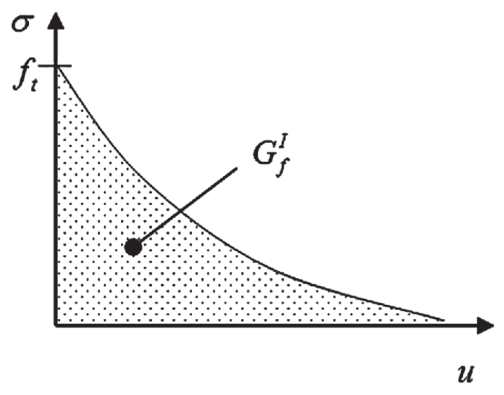

(b)

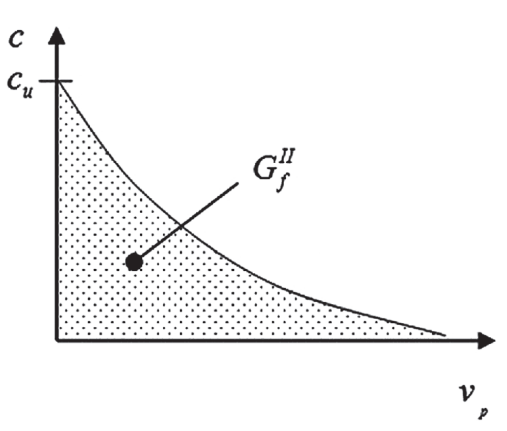

(c) 
the values of concrete cohesion and internal friction angle was determined. Finally, using the statistical curve fitting methods, the following equations were proposed:

$\varphi^{\circ}=0.145 f_{c}^{\prime}(M P a)+49.71$

$c(M P a)=0.1065 f_{c}^{\prime}(M P a)+0.531$

Softening of masonry units can be allowed in DEM. Softening is described using softening rate of tensile strength and cohesion as shown in equation 12 and 13 below (Rots, 1997):

$\sigma=f_{t} e^{-\frac{f_{t}}{G_{f}^{I}} u_{p}}$

$c=c_{u} e^{-\frac{c_{u}}{G_{f}^{I I}} v_{p}}$

where $G_{f}^{I}$ denotes the tensile fracture energy (generally named Mode-I fracture energy) and is defined as the amount of energy to create a unitary area of a tension crack, Figure 5(b). Also, $G_{f}^{I I}$ stands for the shear fracture energy (generally named Mode-II fracture energy) and is defined as the amount of energy to create a unitary area of a shear crack, Figure 5(c). According to Lourenco (1996), parameter $G_{f}^{I}$ for clay bricks ranges from 0.005 to $0.02 \mathrm{~N} . \mathrm{mm} / \mathrm{mm}^{2}$ for a tensile strength ranging from 0.3 to $0.9 \mathrm{MPa}$ and parameter $G_{f}^{I I}$ ranges from 0.01 to $0.25 \mathrm{~N} . \mathrm{mm} / \mathrm{mm}^{2}$ for a cohesion strength ranging from 0.1 to $1.8 \mathrm{MPa}$. These parameters are required to capture the inelastic behavior of concrete masonry blocks using the strain-softening model.

\section{Joints}

For the joints, mortar mechanical behavior can be simulated suing the Mohr-Coulomb slip constitutive law model. For such constitutive law, the inelastic parameter related to the dilation angle is also required. Dilatancy is a measure of the change in volume that occurs when shear stress is applied to a material (Atkinson et al., 1989). This change is characterized by a dilation angle, $\psi_{j}$, which measures the uplift upon shearing. It has been shown (Atkinson et al., 1989; Mosalam et al., 1997) that dilatancy must be taken into account in the analysis of confined masonry structures such as infilled frames. According to Itasca (2004), for concrete material, a typical dilation angle value is that of $12^{\circ}$. In addition, another inelastic material parameter is that of the coefficient of friction angle. For the simulation of steel masonry infill frames, the coefficient of friction between steel components and masonry panel has an influence on the behavior of the model and must be defined. Based on the available literature, a coefficient angle of friction equal to 0.25 can be used for the frame-to-panel interfaces (Dawe \&Seah, 2001). However, it is highly recommended that further experimental studies should be carried out to define such value. 
A problem often encountered when modelling masonry is the unrealistic response when brick interaction occurs close to or at two opposing brick contacts. At this point, numerically, blocks may be locked or hung-up due to the modelling assumptions that brick corners are sharp or have infinite strength. In a real masonry structure this will only occur as a result of stress concentrations. However, simulating such a phenomenon is impractical. A realistic representation can be achieved by rounding the corners of the blocks so that they can smoothly slide past one another when two opposing corners interact. According to Itasca (2004), a short corner rounding length (e.g. 1\% of the block's length) gives a good level of accuracy.

Sarhosis et al. 2015, carried out a series of sensitivity studies supported with regression analysis to investigate the significance of the brick-mortar interface properties (normal and shear stiffnesses, tensile strength, cohesive strength and frictional resistance) on the load at first cracking and ultimate load that a masonry wall panel containing an opening can carry. Computational results were also compared against full scale experimental tests carried out in the laboratory. From the sensitivity analyses it was found that the joint tensile strength is the predominant factor that influences the occurrence of first cracking in the panel, while the cohesive strength and friction angle of the interface influence the behaviour of the panel from the onset of cracking up to collapse.

\section{Steel Frame Material}

Since the steel frame components in a masonry-infilled steel frame are expected to behave in-elastically at ultimate state of loading, a Von-Mises material model must be chosen to represent the steel frame real behavior. The Von-Mises criterion is not available in UDEC. However, according to Itasca (2004), the Drucker-Prager criterion can be degenerated into the Von-Mises criterion when friction angle is equal to zero (i.e. $\varphi=0$ ). Although the steel frame components are made up of steel I-sections, they can be modeled as solid blocks of steel with equivalent elastic and inelastic mechanical properties.

\section{DEM STUDIES ON MASONRY-INFILLED FRAMES}

Although there are many DEM studies in the literature on masonry shear walls, unreinforced masonry buildings, stone masonry arches, ancient structures, colonnades and monuments analysis (Sarhosis et al., 2016), only a few studies have been done on DEM analysis of masonry-infilled RC and steel frames. Some of these few studies are presented in this section.

\section{Masonry-Infilled RC Frames}

In order to evaluate the seismic behavior of masonry walls in rural areas surrounded by reinforced concrete frames (in which the RC frames only provide some binding effect), Sincraian and Azevedo (1998) for the first time analyzed some one-bay and two-story RC frames with different masonry infill panels' configurations using DEM. Elastic isotropic materials were used for both masonry blocks and frame elements. All the frames were subjected to an artificially generated accelerogram matching the elastic response spectrum for soil class A (hard soil) presented in Eurocode 8. The accelerogram were used with different PGA intensities for each model to simulate different severities of the seismic motion. They 
found that the Discrete Element Method can be used to capture the collapse mechanisms of the infilled $\mathrm{RC}$ frames as shown in Figure 6. This figure shows the capability of the DEM in capturing the mixed failure mode of masonry panels as joints separation and sliding.

Lang and Benzoni (2014) developed a DEM model of a confined masonry wall using a micro-modeling strategy. The model could simulate the linear and nonlinear behavior of a confined masonry shear wall subjected to in-plane cyclic loading up to $1 \%$ drift (Figure 7). From Figure 7, the capability of the DEM in capturing the DTC failure mode of the infill panel which is in the form of a step-wise diagonal crack through the bed and head joints is demonstrated.

Chiou et al. $(1998,1999)$ studied the static lateral load behavior of masonry-infilled RC frames using a refined discontinuous deformation analysis (DDA). In those studies, the masonry infill wall and $\mathrm{RC}$ frame were cut into sub-blocks by virtual joints with finite tension and shear strength of mortar and concrete materials, respectively as shown in Figure 8. It was found that the DDA results are in good agreement with experimental results. However, the proposed model has some disadvantages such as:(1) ignoring the bond slip of reinforcement in the RC columns and beam; (2) ignoring mixed tension-shear failure of mortar joints and concrete joints between concrete sub-blocks; (3) not taking into account the possibility of bricks' tensile failure in the infill wall regions with high normal stresses; and (4) considering linear constitutive relations for the bricks and concrete material (Chiou et al. 1998).

Figure 6. Deformed geometry of the masonry infilled $R C$ frames (Sincraian and Azevedo, 1998)
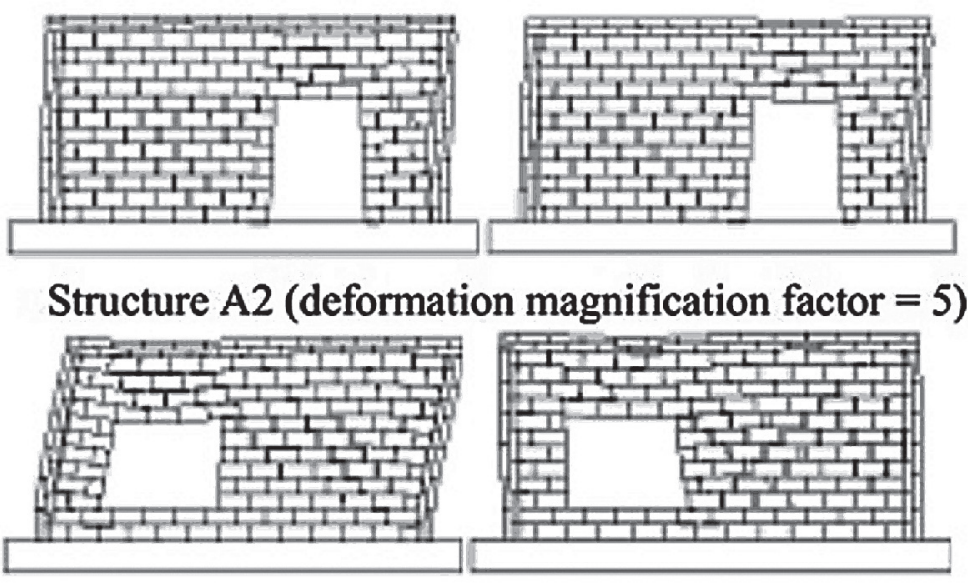

Structure A3 (deformation magnification factor $=5$ )

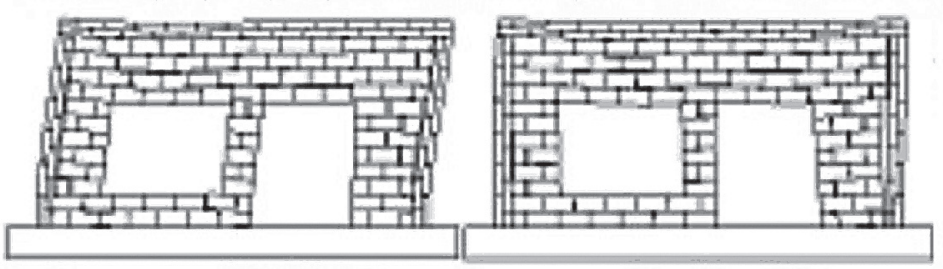

Structure A4 (deformation magnification factor $=5$ ) 
Figure 7. (a) DE model damage pattern and (b) Force-displacement results of experimental and numerical model of a confined masonry wall subjected to cyclic loading (after Lang and Benzoni 2014)

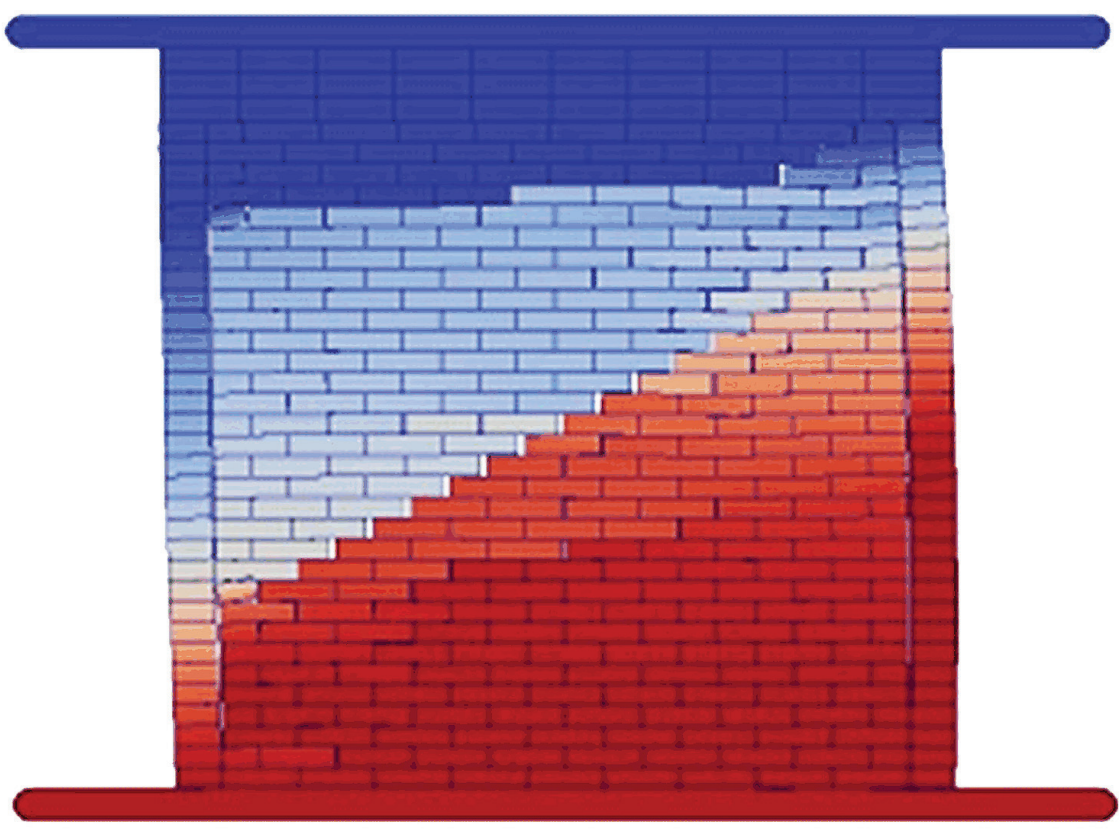

(a)

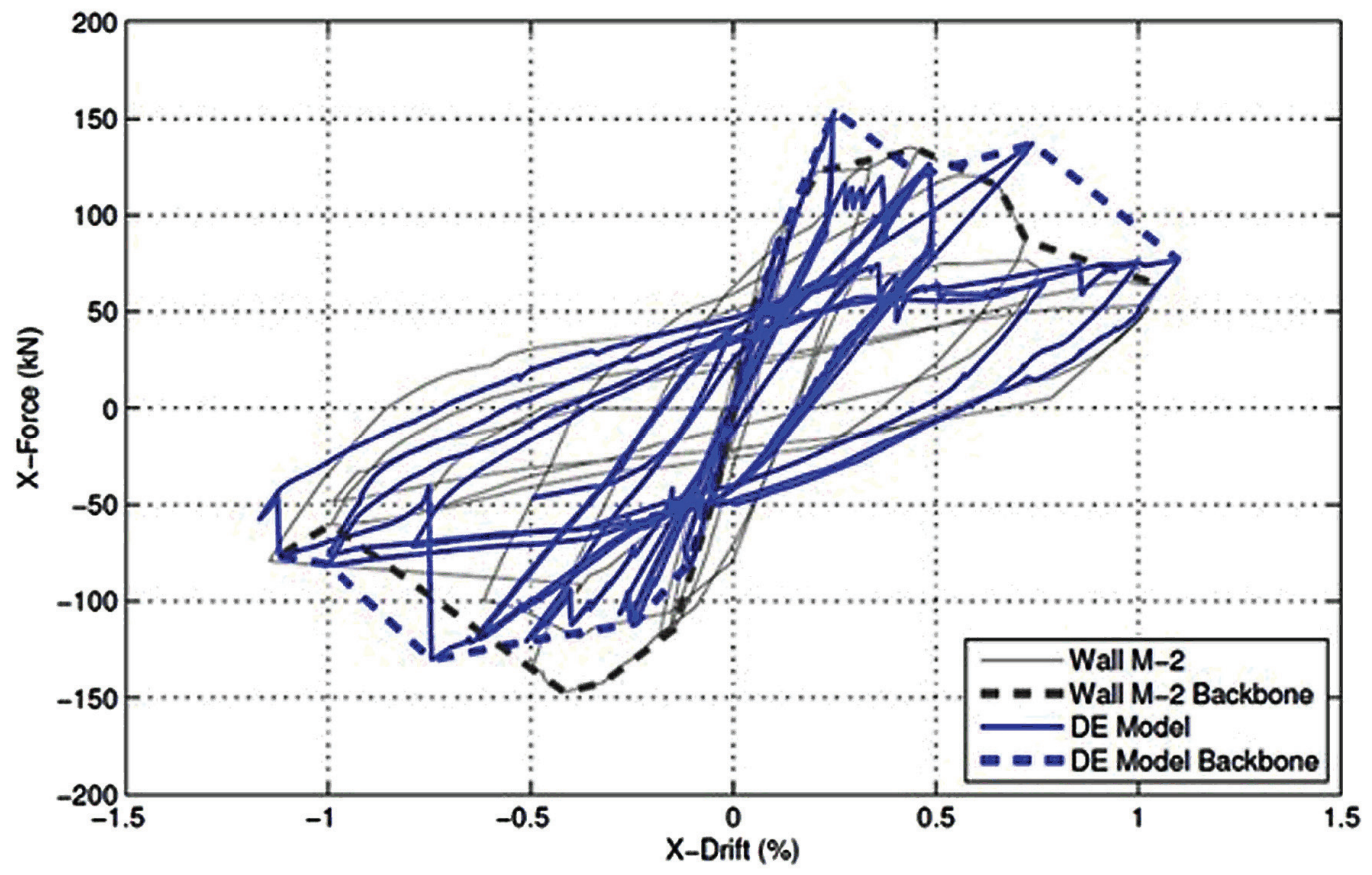

(b) 
Figure 8. Principal stress distribution of a masonry-infilled RC frame using DDA (after Chiou et al. 1998)

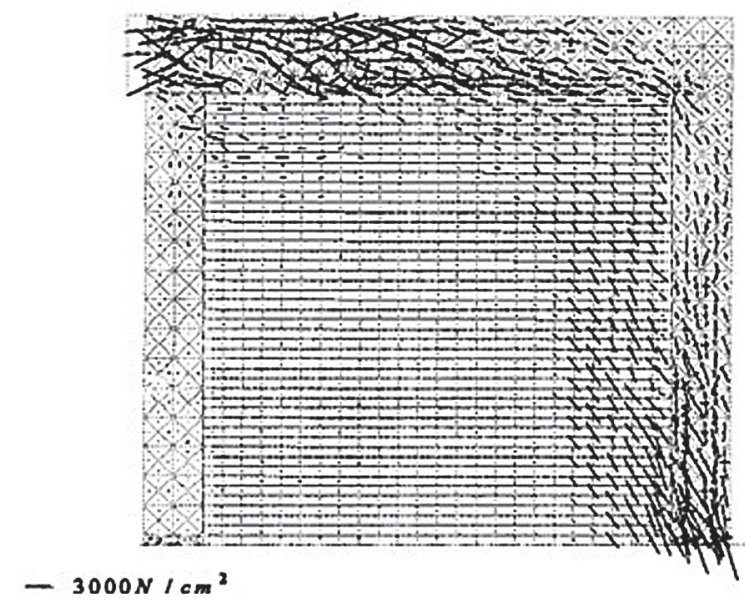

\section{Masonry-Infilled Steel Frames}

\section{Opening Size and Location Effects}

Mohebkhah et al. (2008) developed a two-dimensional numerical model using the specialized discrete element method (DEM) software UDEC (2004) for the nonlinear static analysis of masonry-infilled steel frames with openings subjected to in-plane monotonic loading. It was found that the numerical model is applicable to a simplified micro-modeling simulation of the response of concrete masonry-infilled steel frames with and without openings throughout the loading process leading to failure (as shown in Figure 9) and to predict their failure mechanisms based on joint separation and sliding.

Furthermore, the DEM model was used to investigate the effect of door frame on lateral load capacity and stiffness of infilled frames with a central opening as shown in Figure 10. In addition, Figure 10 shows the capability of the DEM in capturing the DTC and CC failure modes and diagonal step-wise cracking which is consistent reasonably with laboratory experimental observations presented in Dawe and Seah (1989). Mohebkhah and Tasnimi (2012) also used the developed DEM model to simulate the lateral load behavior of some tested clay brick masonry-infilled steel frames in Mohebkhah (2007).

In order to study the effect of non-standard case of positions of openings (as shown for example in Figure 11) on the behavior of steel in-filled frames, Sarhosis et al. (2014b) developed a 2D numerical model using the specialized discrete element method (DEM) software UDEC. The model was used for a series of parametric studies to investigate the significance of the size and location of the openings on the lateral load capacity, as well as the stiffness and failure mechanisms of the infilled steel frames. The effect of the actual loading type on the steel frame has also been investigated by evaluating the responses of two lateral load conditions. The first case was the typical point load on the top left hand corner of the steel frame (Figure 12a), as used in all previous analyses presented in this chapter, while the second case considered a lateral uniformly distributed load at the left hand column of the steel frame (Figure 12b). Comparisons made with respect to the strength and stiffness of the infilled system as well as their 
Figure 9. Lateral load-displacement response of masonry-infilled steel frames Source: Mohebkhah et al. (2008)
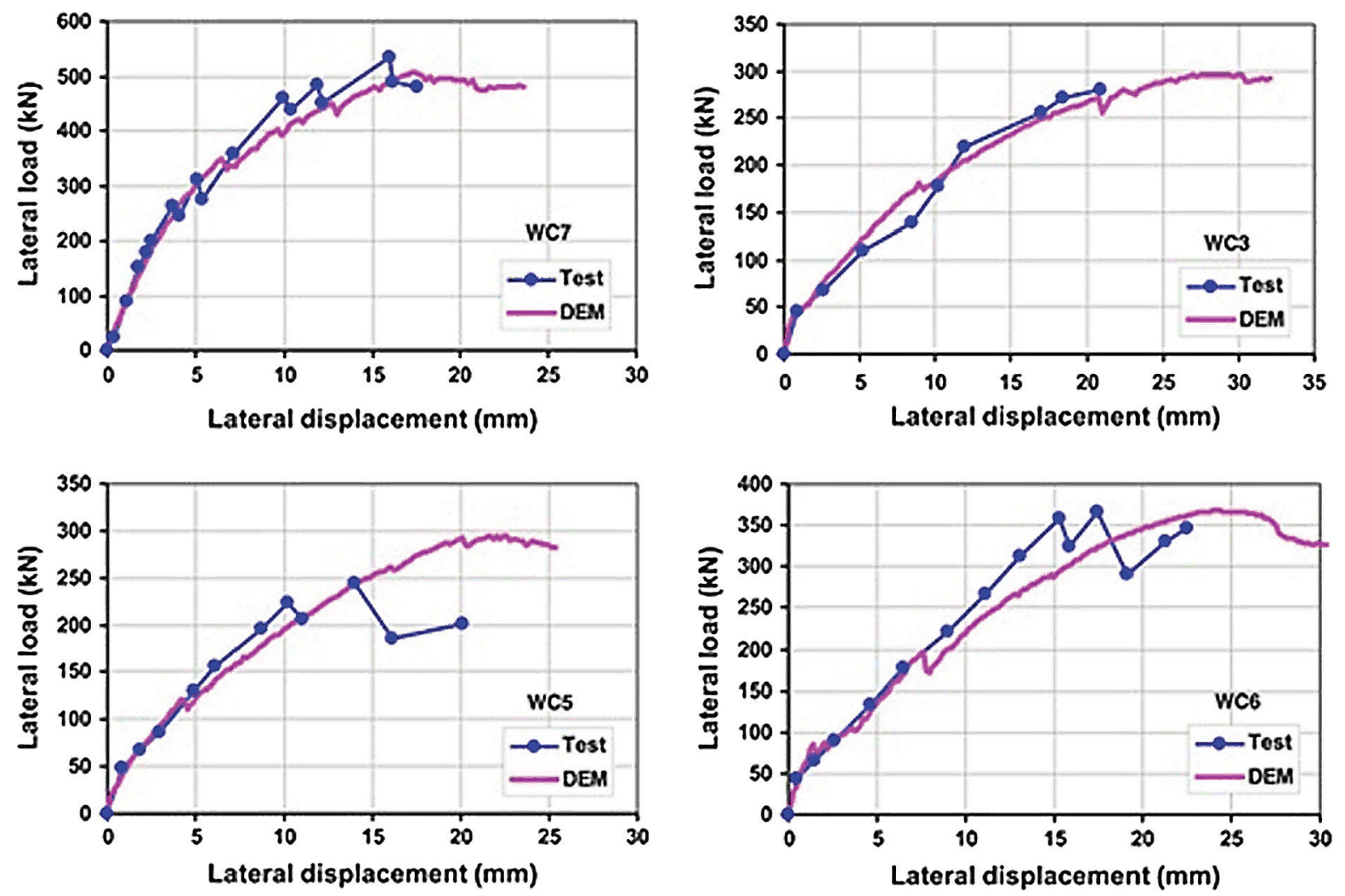

failure mechanisms, in order to draw the main differences and provide better understanding for such cases where, for instance, another frame is in full contact and distributes lateral loads.

From the results analysis, it was found that when the point load was applied on the steel frame, the initial stiffness was relatively high. However, after a certain load (approx. $125 \mathrm{kN}$ ) the stiffness reduced and kept constant up until the failure of the masonry infill panel. On the other hand, the strength of the masonry infill steel frame is lower when the distributed load applied on the steel frame. The main reason resulted this behaviour is that the distributed load applied on the entire column, hence it deflects more affecting the bottom part of the infill, which now deforms severely, leading to higher overall displacements. When a point load applied to the masonry panel, the corresponding load capacity observed was $535 \mathrm{kN}$; the corresponding capacity for the case with the distributed load was $450 \mathrm{kN}$ (Figure 13).

\section{Effect of Gravity Load}

In order to study the effect of gravity loading on the behavior of infilled frames, Mohebkhah (2007) using the developed DEM model, analyzed some tested clay masonry-infilled steel frames. The specimens included one solid infilled frame (SW) and four infilled frames with central openings of different relative openings area (PW1, PW2, PW3 and PW4). The DEM lateral load-displacement curves of the frames as shown in Figure 14 indicated that the presence of gravity loads on columns and top beam 
Figure 10. DEM results of specimen WC3 with a door frame at a horizontal displacement of $23 \mathrm{~mm}$ : (a) blocks' failure points and crack patterns of the joints; (b) magnified principal stress tensors; (c) horizontal displacement contours $(m) ;(d)$ deformed geometry (magnification factor=10); (e) principal finite strain tensors; and $(f)$ bending moment of door frame Source: Mohebkhah et al. (2008)

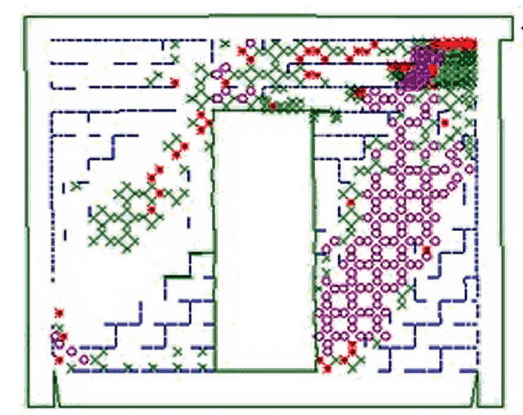

$a$

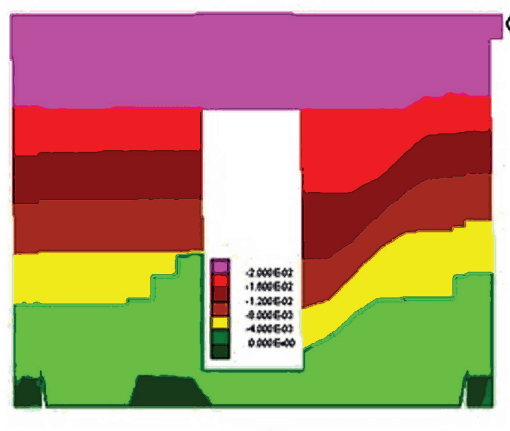

$c$

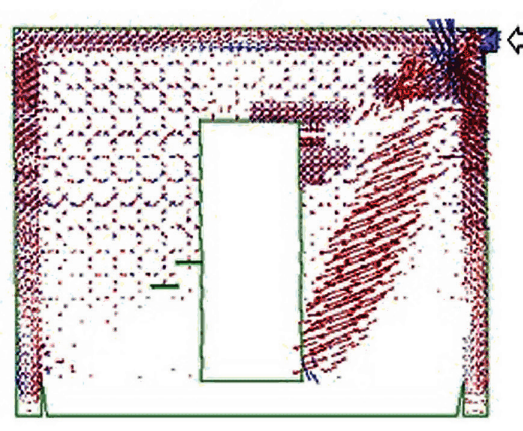

$e$

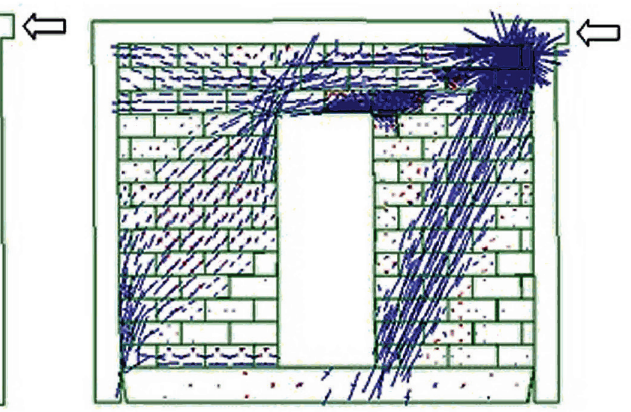

$b$

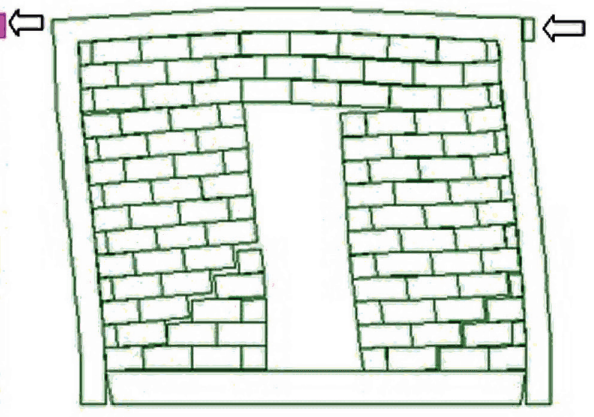

$d$

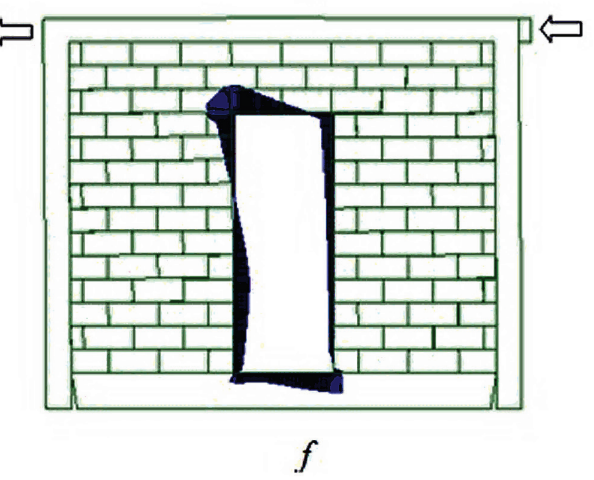

notably reduces the infilled frames lateral stiffness degradation compared to the frames without gravity loads (i.e. curves designated as W/O GL in the figure). It was also observed that applying gravity loads (resulted from the upper stories gravitational loads of a typical three-story infilled frame) resulted in an increase in lateral load capacity of $16 \%$ for specimen SW. However, the increase in lateral capacity for other specimens with openings depends on the opening relative length; as the opening length increases the capacity increase reduces. 
Figure 11. DEM analysis of a masonry-infilled steel frame with multiple openings Source: Sarhosis et al. (2014b)



(a) Deformed shape

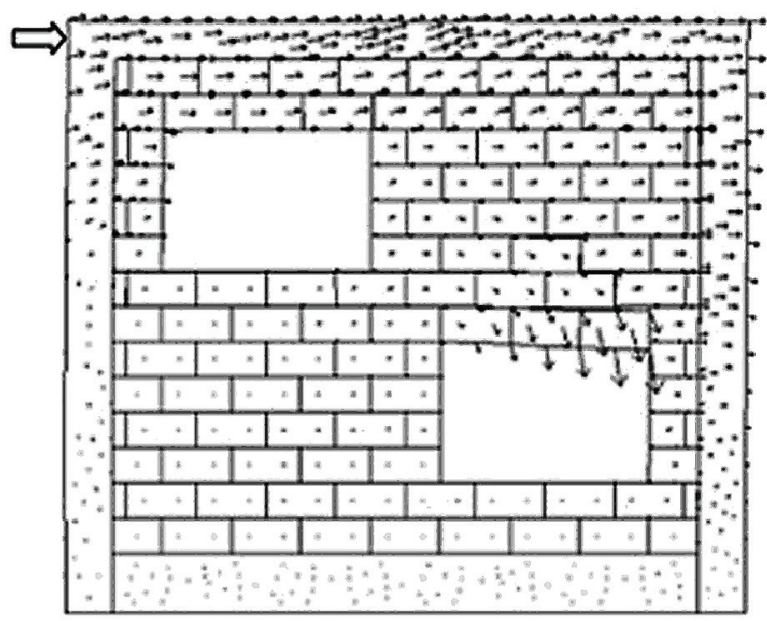

(b) Displacement vectors

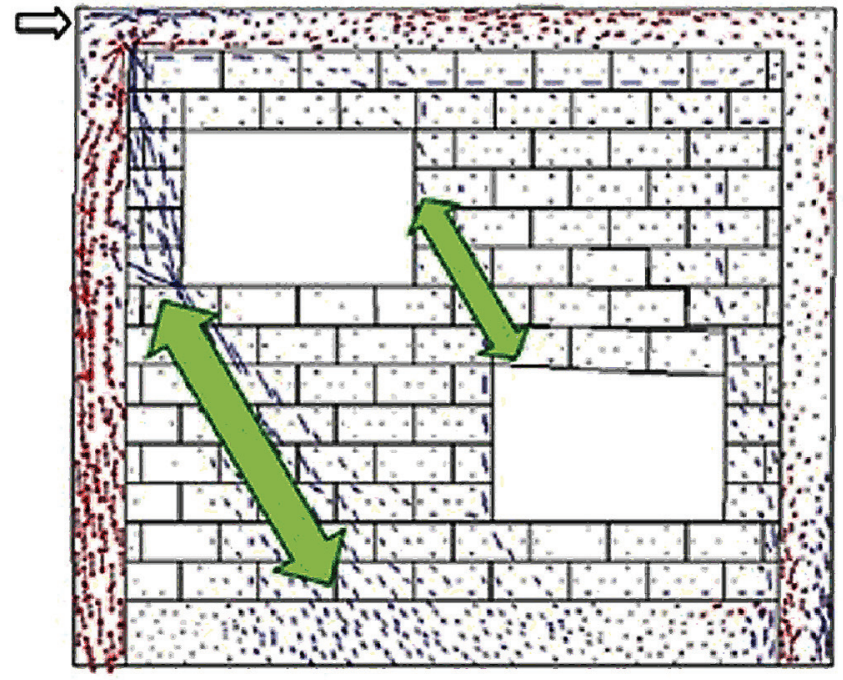

(c) Principal stress tensors

Figure 12. Configurations of load applied to the panel

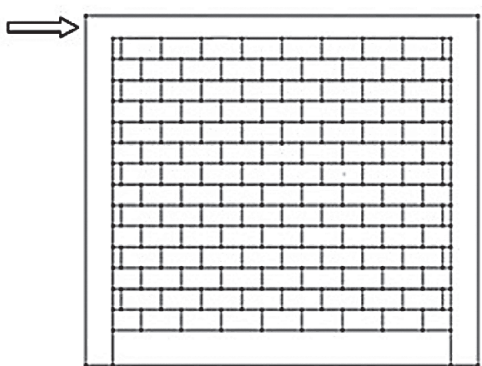

(a) Point Load

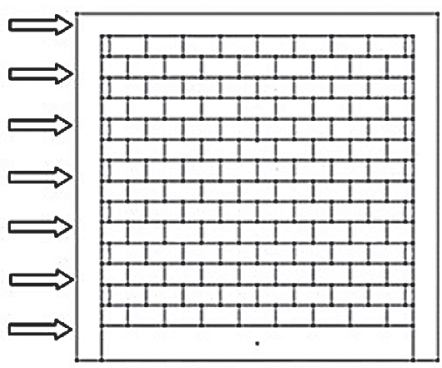

(b) Uniformly Distributed Load 
Figure 13. Load displacement behaviour for both loading conditions

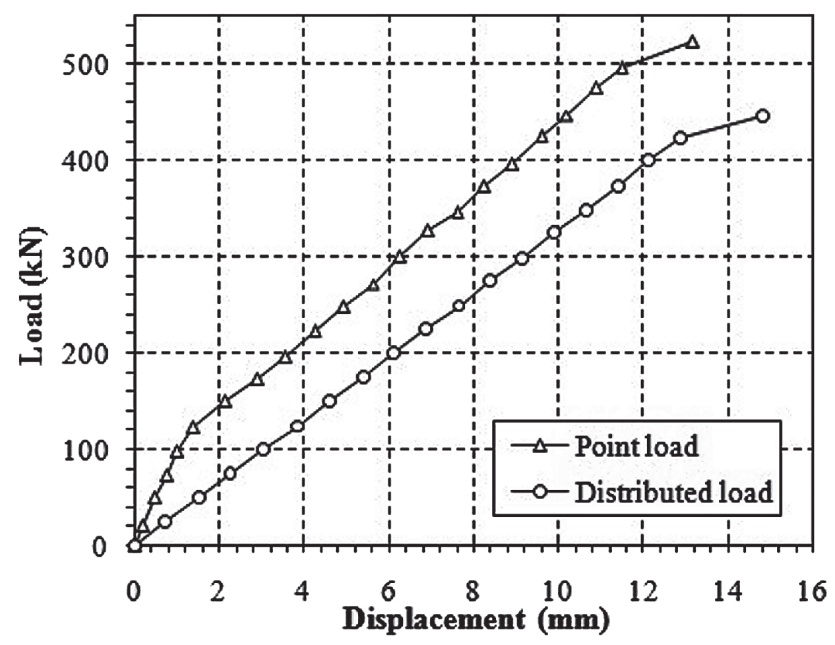

Figure 14. Effect of gravity loads on lateral load-displacement response of masonry-infilled steel frames using DEM

Source: Mohebkhah (2007)
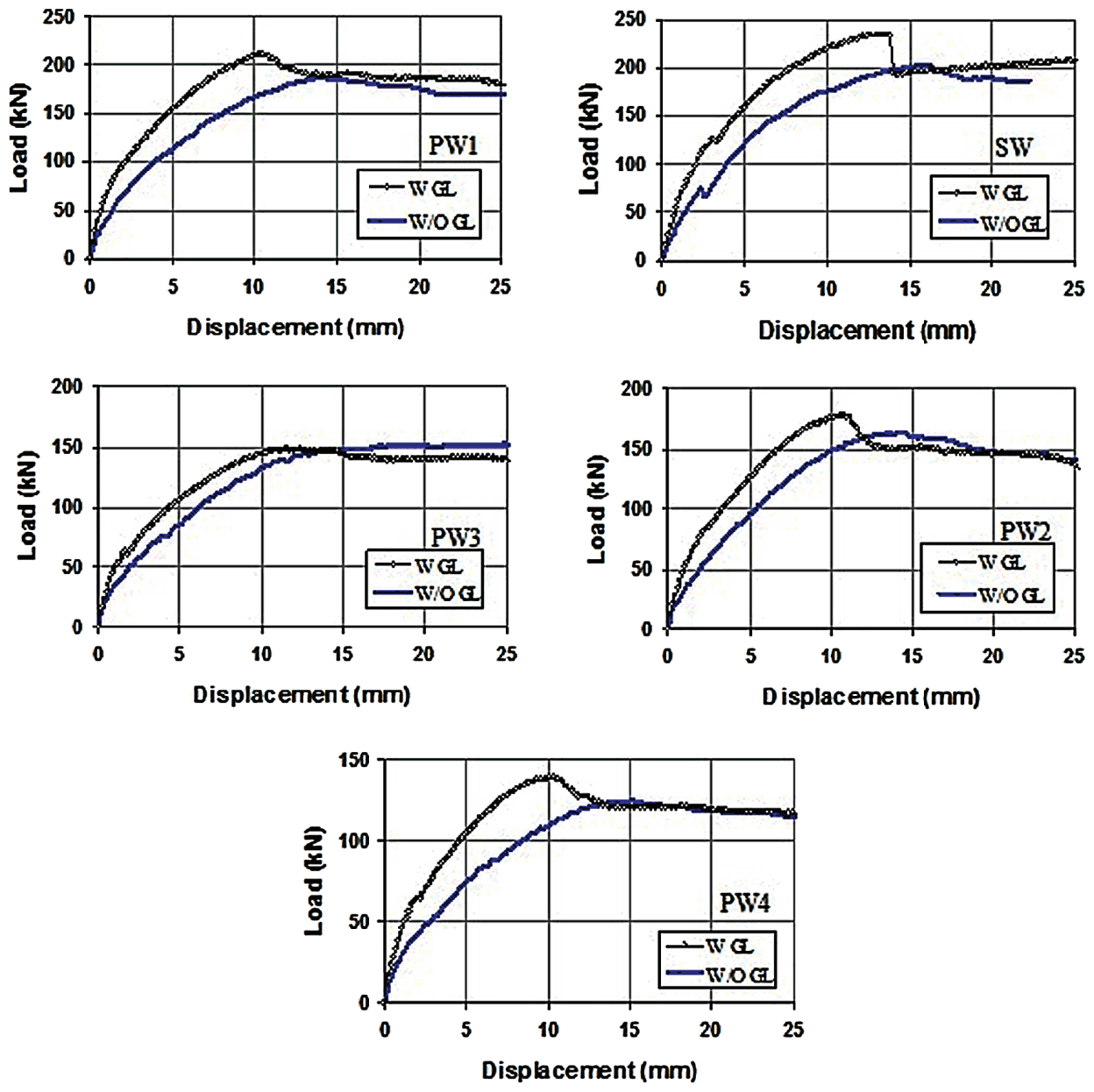
It should also be noted that, although applying gravity loads increases the frames' capacity, however, the frames behavior becomes more or less brittle.

\section{CONCLUSION}

Framed buildings in urban areas are usually infilled with masonry as interior and exterior walls. The resulting system is referred to as an infilled frame, which has high in-plane stiffness and strength. Although, such frames are analyzed and designed without taking into account the effects of infill panels, however, the lessons learned from the past earthquakes indicate that often, the infill panels can stabilize the buildings against lateral loads through increasing their stiffness and strength. Hence, the effects of infill panels in the analysis and design processes of such frames as well as seismic vulnerability of existing infilled frames is of major concern for the engineers. As experimental research is prohibitively expensive, it is fundamentally important to have available computational tools that can be used to predict the mechanical behaviour of the infill panels with sufficient reliability. Once such tools have been established, they can be used to investigate a range of complex problems and scenarios that would not, otherwise, be possible.

Numerical modeling of masonry-infilled frames presents many difficulties. These arise from the existence of joints as the major source of weakness and material nonlinearities as well as the infill-frame interaction. Numerical modeling strategies of infilled frames are divided into two distinct categories, micro-modeling and macro-modeling. For micro-modeling of masonry-infilled frames, both the surrounding frame and the infill panel components details are modeled and analyzed using a numerical method such as finite element method (FEM) or distinct/discrete element method (DEM). In this strategy, the interaction between masonry units along the joints as well as the frame-infill panel interaction is taken into account. The available finite element programs include interface elements that allow the user to incorporate properly masonry discontinuities in the analysis of infilled frames. However, as an alternative to the available finite element methods, discrete/distinct element method (DEM) can also be used to investigate the nonlinear lateral load behavior of masonry-infilled frames. Discrete element method has the capability to consider large displacements, shear sliding and complete joints openings between masonry units as well as automatic detection of new contact points during the numerical analysis process considering no explicit interface elements between the masonry units. In this method, individual masonry units can be modeled as either rigid or deformable material. Deformable units are subdivided into a mesh of finite-difference elements and each element responds according to a prescribed linear or nonlinear stress-strain law. From the analysis of masonry-infilled framed structures, it was shown that the swaying of the frames causes partial separation of the panel and the frame. In terms of the sway of masonry-infilled frames, a similar mechanism is noticed to that of a bare frame however to a much lesser degree. Once separated, the only point of contact can be found at the loaded corner and the diagonally opposite corner of the frame. Failure of the masonry infill panel could be described by the following four modes: diagonal cracking; localised crushing of the bricks/ blocks; sliding through the mortar or a combination of diagonal and sliding failure. Current studies suggest that localising crushing is the most common failure mode. Failure predominantly occurs in the loaded corner of the frame and diagonally opposite corner. The overall strength and stiffness is affected through variation in connections between the column and the panel, strength of the mortar and blocks and the rigidity of the frame. Also, cracking occurs mainly within the mortar through diagonal and sliding failure. The diagonal cracks propagated 
along the compression diagonal which runs from the loaded corner down to the opposite corner. Different models and experiments have resulted varying results in terms of the compression areas once the load is applied. Compression strut models have been carried out since the 1960s. In relation to masonry infilled frames containing openings, the openings within the masonry panel affect the lateral resistance of the frame, the failure mode and the ultimate load carrying capacity of the frame. From both experimental and analytical studies, it has been shown that changing the position of a door opening within the panel affects the lateral ultimate load. Also, the further away the opening is from the location of the application of the external load, the higher the load that the structure can resist. As the size of the opening increases the overall stiffness and strength of the system reduces. When the opening is located towards the compression diagonal the overall strength and stiffness is adversely affected. Stiffness has been monitored through stiffness factor values and interpreting load-displacement profiles of the frames. Failure modes similar to solid infills occur with corner crushing of the bricks close to the applied load and diagonal stepped cracking was found.

The discrete element method and in particular the UDEC software has been proved to accurately represent the experimental test results and predict the failure mechanisms and the strength and stiffness of the masonry infilled panels. According to the experience of the authors, the advantage of discrete element method for modeling masonry infill steel framed structures lies in the fact that each brick is considered individually and large displacement and rotations of masonry units are allowed. Also, within DEM the geometrical, physical and mechanical characteristics of a masonry structure can be represented realistically. This is opposed to other numerical methods where continuity theories are used to simplify the masonry structure into an unrealistic continuum medium. Moreover, the use of DEM for modelling infill wall panels can be used to predict accurately the location and magnitude of surface crack widths between adjacent masonry blocks. In this way, the serviceability limit state performance of masonry structures can be estimated accurately. However, it is worth highlighting that the size of the simulation is limited by the number of masonry units which is a function of the available computing power and that the accuracy of the results is highly dependent on the reliability of the material parameters. However, nowadays, with the fast development of fast processors and parallel programming, computational issues related to the analysis and execution of numerical simulations are becoming less of an issue.

\section{REFERENCES}

Achyutha, H., Jagadish, R., Rao, P. S., \& Shakeebur, R. S. (1986). Finite element simulation of the elastic behavior of infilled frames with openings. Computers \& Structures, 23(5), 685-696. doi:10.1016/00457949(86)90077-5

Asteris, P. G. (2003). Lateral stiffness of brick masonry infilled plane frames. Journal of Structural Engineering, 129(8), 1071-1079. doi:10.1061/(ASCE)0733-9445(2003)129:8(1071)

Asteris, P. G., Cotsovos, D. M., Chrysostomou, C. Z., Mohebkhah, A., \& Al-Chaar, G. K. (2013). Mathematical micromodeling of infilled frames: State-of-the-art. Engineering Structures, 56, 1905-1921. doi:10.1016/j.engstruct.2013.08.010 
Asteris, P. G., Sarhosis, V., Mohebkhah, A., Plevris, V., Papaloizou, P., Komodromos, P., \& Lemos, J. V. (2015). Numerical Modeling of Historic Masonry Structures. In Seismic Assessment and Rehabilitation of Historic Structures. IGI Global. doi:10.4018/978-1-4666-8286-3

Atkinson, R. H., Amadei, B. P., Saeb, S., \& Sture, S. (1989). Response of masonry bed joints in direct shear. Journal of Structural Engineering, 115(9), 2276-2296. doi:10.1061/(ASCE)0733-9445(1989)115:9(2276)

Azevedo, J. J., Sincraian, G. E., \& Lemos, J. V. (2000). Seismic behavior of blocky masonry structures. Earthquake Spectra, 16(2), 337-365. doi:10.1193/1.1586116

Bićanić, N., Ponniah, D., \& Robinson, J. (2001). Computational modelling of masonry, brickwork and blockwork structures. In J. W. Bull (Ed.), Discontinuous Deformation Analysis of Masonry Bridges. Edinburgh, UK: Saxe-Coburg Publications.

Bobet, A., Fakhimi, A., Johnson, S., Morris, J., Tonon, F., \& Yeung, M. R. (2009). Numerical models in discontinuous media, review of advances for rock mechanics applications. Journal of Geotechnical and Geoenvironmental Engineering, 135(11), 1547-1561. doi:10.1061/(ASCE)GT.1943-5606.0000133

Chen, W. F. (1982). Plasticity in reinforced concrete. New York: McGraw-Hill.

Chen, X., \& Liu, Y. (2015). Numerical study of in-plane behaviour and strength of concrete masonry infills with openings. Engineering Structures, 82, 226-235. doi:10.1016/j.engstruct.2014.10.042

Claxton, M., Hart, R. A., McCombie, P. F., \& Walker, P. J. (2005). Rigid block distinct-element modeling of dry-stone retaining walls in plane strain. Journal of Geotechnical and Geoenvironmental Engineering, 131(3), 381-389. doi:10.1061/(ASCE)1090-0241(2005)131:3(381)

Cundall, P. A. (1971). A Computer Model for Simulating Progressive Large Scale Movements in Blocky Rock Systems. In Proceedings of the Symposium of the International Society for Rock Mechanics.

Dawe, J. L., \& Seah, C. K. (1989). Behavior of masonry infilled steel frames. Canadian Journal of Civil Engineering, 16(6), 865-876. doi:10.1139/189-129

Dawe, J. L., Seah, C. K., \& Liu, Y. (2001). A computer model for predicting infilled frame behavior. Canadian Journal of Civil Engineering, 28(1), 133-148. doi:10.1139/100-083

Dhanasekar, M., \& Page, A. W. (1986). Influence of brick masonry nfill properties on the behaviour of infilled frames. Proc, Inst Civil Engrs. Lond, 81(Part 2), 593-605.

El-Dakhakhni, W. W. (2002). Experimental and analytical seismic evaluation of concrete masonry-infilled steel frames retrofitted using GFRP laminates. (Ph.D. thesis). Drexel University, Philadelphia, PA.

El-Dakhakhni, W. W., Elgaaly, M., \& Hamid, A. A. (2003). Three-strut model for concrete masonryinfilled steel frames. Journal of Structural Engineering, 129(2), 177-185. doi:10.1061/(ASCE)07339445(2003)129:2(177)

Flanagan, R. D., \& Bennett, R. M. (1999). In-plane behavior of structural clay tile infilled frames. Journal of Structural Engineering, 125(6), 590-599. doi:10.1061/(ASCE)0733-9445(1999)125:6(590) 
Gambarotta, L., \& Lagomarsino, S. (1997). Damage models for the seismic response of brick masonry shear walls. Part I: The mortar joint model and its applications. Journal of Earthquake Engineering and Structural Dynamics, 26(4), 423-439. doi:10.1002/(SICI)1096-9845(199704)26:4<423::AIDEQE650>3.0.CO;2-\#

Ghosh, A. K., \& Made, A. M. (2002). Finite element analysis of infilled frames. Journal of Structural Engineering, 128(7), 881-889. doi:10.1061/(ASCE)0733-9445(2002)128:7(881)

Giamundo, V., Sarhosis, V., Lignola, G. P., Sheng, Y., \& Manfredi, G. (2014). Evaluation of different computational strategies for modelling low strength masonry. Engineering Structures, 73, 160-169. doi:10.1016/j.engstruct.2014.05.007

Giordano, A., Mele, E., \& Luca, A. (2002). Modelling of historical masonry structures.Comparison of different approaches through a case study. Engineering Structures, 24(8), 1057-1069. doi:10.1016/ S0141-0296(02)00033-0

Itasca Consulting Group, Inc. (2004). UDEC- Universal Distinct Element Code, version 4.0- User's manual. Minneapolis, MN: Author.

Jing, L. (2003). A review of techniques, advances and outstanding issues in numerical modelling for rock mechanics and rock engineering. International Journal of Rock Mechanics and Mining Sciences, 40(3), 283-353. doi:10.1016/S1365-1609(03)00013-3

King, G. J. W., \& Pandey, P. C. (1978). The analysis of infilled frames using finite elements. Proceedings - Institution of Civil Engineers, 65(Part 2), 749-760. doi:10.1680/iicep.1978.2707

Koutromanos, I. (2011). Numerical analysis of masonry-infilled reinforced concrete frames subjected to seismic loads and experimental evaluation of retrofit techniques. (Ph.D. thesis). University of California, San Diego, CA.

Koutromanos, I., Stavridis, A., Shing, P. B., \& Willam, K. (2011). Numerical modeling of masonryinfilled RC frames subjected to seismic loads. ComputStruct., 89, 1026-1037.

Lang, A. F., \& Benzoni, G. (2014). Modeling of nonlinear behavior of confined masonry using discrete elements. In Proceedings of the $10^{\text {th }}$ National Conf. on Earthquake Engineering. Frontier of Earthquake Engineering.

Lemos, J. V. (1997). Discrete element modeling of the seismic behavior of stone masonry arches. Computer Methods in Structural Masonry- 4.

Lemos, J. V. (2007). Discrete element modeling of masonry structures. International Journal of Architectural Heritage, 1(2), 190-213. doi:10.1080/15583050601176868

Liauw, T. C., \& Kwan, K. H. (1985). Unified plastic analysis for infilled frames. Journal of Structural Engineering, 111(7), 1427-1448. doi:10.1061/(ASCE)0733-9445(1985)111:7(1427)

Liu, Y., \& Manesh, P. (2013). Concrete masonry infilled steel frames subjected to combined in-plane lateral and axial loading - An experimental study. Engineering Structures, 52, 331-339. doi:10.1016/j. engstruct.2013.02.038 
Lofti, H. R., \& Shing, P. B. (1994). Interface model applied to fracture of masonry structures. Journal of Structural Engineering, 120(1), 63-80. doi:10.1061/(ASCE)0733-9445(1994)120:1(63)

Lourenco, P. B. (1996). Computational strategies for masonry structures. (Ph.D. thesis). Delft University of Technology, Delft, The Netherlands.

Lourenco, P. B., Oliveira, D. V., Roca, P., \& Orduna, A. (2005). Dry joint masonry walls subjected to in-plane combined loading. Journal of Structural Engineering, 131(11), 1665-1673. doi:10.1061/ (ASCE)0733-9445(2005)131:11(1665)

Lourenço, P. B., \& Rots, J. G. (1997). A multi-surface interface model for the analysis of masonry structures. Journal of Engineering Mechanics, 123(7), 660-668. doi:10.1061/(ASCE)0733-9399(1997)123:7(660)

Madan, A., Reinhorn, A. M., Mander, J. B., \& Valles, R. E. (1997). Modeling of masonry infill panels for structural analysiss. Journal of Structural Engineering, 123(10), 1295-1302. doi:10.1061/(ASCE)07339445(1997)123:10(1295)

Markulak, D., Radic', I., \& Sigmund, V. (2013). Cyclic testing of single bay steel frames with various types of masonry infill. Engineering Structures, 51, 167-277. doi:10.1016/j.engstruct.2013.01.026

Mehrabi, A. B., \& Shing, P. B. (1997). Finite element modeling of masonry-infilled RC frames. Journal of Structural Engineering, 123(5), 604-613. doi:10.1061/(ASCE)0733-9445(1997)123:5(604)

Moghaddam, H. A. (2004). Lateral load behavior of masonry infilled steel frames with repair and retrofit. Journal of Structural Engineering, 130(1), 56-63. doi:10.1061/(ASCE)0733-9445(2004)130:1(56)

Moghaddam, H. A., \& Dowling, P. J. (1987). The state-of-the-art in infilled frames. ESEE Res. Rep. No. 87-2, Imperial Coll. of Sci. and Technol. London: Civ. Eng. Dept.

Moghaddam, H. A., Mohammadi, M. G. H., \& Ghaemian, M. (2006). Experimental and analytical investigation into crack strength determination of infilled steel frames. Journal of Constructional Steel Research, 62(12), 1341-1352. doi:10.1016/j.jcsr.2006.01.002

Mohebkhah, A. (2007). A nonlinear-seismic model for brick masonry-infill panels with openings in steel frames. (Ph.D. Dissertation). TarbiatModares University, Tehran, Iran.

Mohebkhah, A., \& Sarv-Cheraghi, A. A. (2015). Nonlinear analysis of unreinforced masonry buildings using distinct element method[in Persian]. Modares CivilEngineering Journal, 15(3), 85-91, Tehran, Iran.

Mohebkhah, A., \& Tasnimi, A. A. (2007). Seismic behavior of brick masonry walls recommended by IS-2800: experimental and numerical approaches. In Proceedings of the 5thConf. on Seismology and Earthquake Engineering. International Institute of Earthquake Engineering and Seismology.

Mohebkhah, A. and Tasnimi, A.A. (2012). Distinct element modeling of masonry-infilled steel frames with openings. The Open Construction and Building Technology Journal, 6(Suppl 1-M2), 42-49.

Mohebkhah, A., Tasnimi, A. A., \& Moghadam, H. A. (2008). Non-linear analysis of masonry in-filled frames with opening using discrete element method. Journal of Constructional Steel Research, 64(21), 1463-1472. doi:10.1016/j.jcsr.2008.01.016 
Mosalam, K. M., White, R. N., \& Gergely, P. (1997). Static response of infilled frames using quasi-static experimentation. Journal of Structural Engineering, 123(11), 1462-1469. doi:10.1061/(ASCE)07339445(1997)123:11(1462)

Mosalam, K. M., White, R. N., \& Gergely, P. (1997). Computational strategies for frames with infill walls: discrete and smeared crack analysis and seismic fragility. Technical Report NCEER-97-0021. National Center for Earthquake Engineering Research, State Univ. of N.Y. at Buffalo.

Paulay, T., \& Priestley, M. J. N. (1992). Seismic design of reinforced concrete and masonry buildings. New York, NY: John Wiley \& Sons, Inc. doi:10.1002/9780470172841

Polyakov, S. V. (1956). Masonry in framed buildings. In Translated by G. L. Cairns in 1963. Boston Spa, UK: National Lending Library for Science and Technology.

Psycharis, I. N., Lemos, J. V., Papastamatiou, D. Y., Zambas, C., \& Papantonopoulos, C. (2003). Numerical study of the seismic behavior of a part of the Parthenon Pronaos. Earthquake Engineering \& Structural Dynamics, 32(13), 2063-2084. doi:10.1002/eqe.315

Psycharis, I. N., Papastamatiou, D. Y., \& Alexandris, A. P. (2000). Parametric investigation of the stability of classical columns under harmonic and earthquake excitations. Earthquake Engineering \& Structural Dynamics, 29(8), 1093-1109. doi:10.1002/1096-9845(200008)29:8<1093::AID-EQE953>3.0.CO;2-S

Riddington, J. R., \& Stafford-Smith, B. (1977). Analysis of infilled frames subjected to racking with design recommendations. The Structural Engineer, 55(6), 263-268.

Rots, J. G. (1997). Structural masonry: an experimental/numerical basis for practical design rules. Center for Civil Engineering Research and Codes (CUR). Balkema.

Saneinejad, A., \& Hobbs, B. (1995). Inelastic design of infield frames. Journal of Structural Engineering, 121(4), 634-650. doi:10.1061/(ASCE)0733-9445(1995)121:4(634)

Sarhosis, V., Garrity, S. W., \& Sheng, Y. (2008). Distinct element modelling of masonry wall panels with openings. 9th International Conference on Computational Structures Technology, Athens, Greece.

Sarhosis, V., Garrity, S. W., \& Sheng, Y. (2015). Influence of the brick-mortar interface on the mechanical response of low bond strength masonry lintels. Engineering Structures, 88, 1-11. doi:10.1016/j. engstruct.2014.12.014

Sarhosis, V., Lignola, G. P., \& Asteris, P. (2016). Seismic Vulnerability of Ancient Colonnade: Numerical analysis of the two storey colonnade of the Forum in Pompeii. In Asteris \& Repapis (Eds.), Seismic Assessment and Rehabilitation of Historic Structures. IGI Global.

Sarhosis, V., Oliveira, D. V., Lemos, J. V., \& Lourenco, P. (2014a). The effect of the angle of skew on the mechanical behaviour of arches. Journal of Mechanics Research Communications, 61, 53-49. doi:10.1016/j.mechrescom.2014.07.008

Sarhosis, V., \& Sheng, Y. (2014). Identification of material parameters for low bond strength masonry. Engineering Structures, 60, 100-110. doi:10.1016/j.engstruct.2013.12.013 
Sarhosis, V., Tsavdaridis, K., \& Giannopoulos, G. (2014b). Discrete Element Modelling of masonry in-filled steel frames with multiple window openings subjected to lateral load variations. The Open Construction and Building Technology Journal, 8(1), 93-103. doi:10.2174/1874836801408010093

Schlegel, R., \& Rautenstrauch, K. (2004). Failure analyses of masonry shear walls. In H. Konietzky (Ed.), Numerical modelling of discrete materials in geotechnical engineering, civil engineering and earth sciences (pp. 15-20). Taylor and Francis Group London.

Schneider, S. P., Zagers, B. R., \& Abrams, D. P. (1998). Lateral strength of steel frames with masonry infills having large openings. Journal of Structural Engineering, 124(8), 896-904. doi:10.1061/ (ASCE)0733-9445(1998)124:8(896)

Sharma, V. M., Saxena, K. R., \& Woods, R. D. (1999). Distinct Element Modeling in Geomechanics. Rotterdam: A. A. Balkema.

Shi, G. H., \& Goodman, R. E. (1988). Discontinuous deformation analysis - a new method for computing stress, strain and sliding of block systems. In P.A. Cundall, R. Sterling, \& A. Starfield (Eds.), Proceedings of the 29th U.S. Symposium: Key Questions in Rock Mechanics.

Sincraian, G. E., \& Azevedo, J. J. (1998). Numerical simulation of the seismic behavior of stone and brick masonry structures.Proc. of the 11th European Conference on Earthquake Engineering. Balkema.

Sincraian, G. E., Lemos, J. V., \& Oliveira, C. S. (1998). Assessment of the seismic behavior of stone masonry aqueduct using the discrete element method.Proc. 11th European Conference on Earthquake Engineering. Balkema.

Stafford-Smith, B. (1962). Lateral stiffness of infilled frames. Journal of the Structural Division, 88(6), 183-199.

Stafford-Smith, B. (1966). Behavior of square infilled frames. Journal of the Structural Division, 92(1), 381-403.

Stavridis, A. (2009). Analytical and experimental study of seismic performance of reinforced concrete frames infilled with masonry walls. (PhD thesis). Department of Structural Engineering, University of California, San Diego, CA.

Stavridis, A., \& Shing, P. B. (2010). Finite-element modeling of nonlinear behavior of masonry-infilled RC frames. Journal of Structural Engineering, 136(3), 285-296. doi:10.1061/(ASCE)ST.1943-541X.116

Tasnimi, A. A., \& Farzin, M. (2006). Inelastic behavior of RC columns under cyclic loads based on cohesion and internal friction angle of concrete. Modarres Technical and Engineering Journal, 23, 29-40.

Tasnimi, A. A., \& Mohebkhah, A. (2011). Investigation on the behavior of brick-infilled steel frames with openings, experimental and analytical approaches. Engineering Structures, 33(3), 968-980. doi:10.1016/j.engstruct.2010.12.018

Toth, A. R., Orban, Z., \& Bagi, K. (2009). Discrete element analysis of stone masonry arch. Mechanics Research Communications, 36(4), 469-480. doi:10.1016/j.mechrescom.2009.01.001 


\section{ADDITIONAL READING}

Al-Chaar, G., Issa, M., \& Sweeney, S. (2002). Behavior of masonry-infilled nonductile reinforced concrete frames. Journal of Structural Engineering, 128(8), 1055-1063. doi:10.1061/(ASCE)07339445(2002)128:8(1055)

Al-Chaar, G. L., \& Mehrabi, A. (2008). Constitutive models for nonlinear finite element analysis of masonry prisms and infill walls (No. ERDC/CERL TR- 08-19). US Army Corps of Engineering.

Almeida, J. C., Lourenco, P. B., \& Barros, J. A. (2002). Characterization of brick and brick-mortar interface under uniaxial tension, in: Proceedings of 7th Int. Seminar on Structural Masonry, Brazil: CEFET-MG. 67-76.

Amato, G., Cavaleri, L., \& Fossetti, M. (2008). Infilled frames: Influence of vertical load on the equivalent diagonal strut model. Presented at the 14 WCEE, Beijing, China.

Braga, F., Gigliotti, R., Laterza, M., D’Amato, M., \& Kunnath, S. (2012). Modified steel bar model incorporating bond-slip for seismic assessment of concrete structures. Journal of Structural Engineering, 138(11), 1342-1350. doi:10.1061/(ASCE)ST.1943-541X.0000587

Buonopane, S., \& White, R. (1999). Pseudodynamic testing of masonry infilled reinforced concrete frame. Journal of Structural Engineering, 125(6), 578-589. doi:10.1061/(ASCE)0733-9445(1999)125:6(578)

Calvi, G. M., \& Bolognini, D. (2001). Seismic response of reinforced concrete frames infilled with weakly reinforced masonry panels. Journal of Earthquake Engineering, 5(2), 153-185. doi:10.1080/13632460109350390

Calvi, G.M., Bolognini, D., Penna, A., (2004). Seismic performance of masonry-infilled RC frames: benefits of slight reinforcement. SÍSMICA 2004 - 6 o Congreso Nacional de Sismología e Engeñaría Sísmica.

Cavaleri, L., Fossetti, M., \& Papia, M. (2004). Effect of vertical loads on lateral response of infilled frames. Presented at the 13WCEE, Vancouver, B.C., Canada.

Fiorato, A. E., Sozen, M. A., \& Gamble, W. L. (1970). Behavior of five-story reinforced concrete frames with filler walls, Interim report to the Department of Defense Office of Secretary of the Army. Urbana, Illinois: Office of Civil Defense.

Fiorato, A. E., Sozen, M. A., \& Gamble, W. L. (1970). An investigation of the interaction of reinforced concrete frames with masonry filler walls (No. UILU-ENG-70-100). Urbana- Champaign, IL: Dept. of Civil Engineering, University of Illinois.

Flanagan, R. D., \& Bennett, R. M. (1999). Arching of masonry infilled frames: Comparison of analytical methods. Practice Periodical on Structural Design and Construction, 4(3), 105-110. doi:10.1061/ (ASCE)1084-0680(1999)4:3(105)

Gabrielsen, B. L., \& Kaplan, K. (1997). Arching in masonry walls subjected to out-of-plane forces. Earthquake Resistant Masonry Construction. NBS Building Science Series, 106, 283-313. 
Gumaste, K. S., Nanjunda Rao, K. S., Venkatarama Reddy, B. V., \& Jagadish, K. S. (2006). Strength and elasticity of brick masonry prisms and wallets under compression. Materials and Structures, 40(2), 241-253. doi:10.1617/s11527-006-9141-9

Hamburger, R. O., \& Meyer, J. D. (2006). The performance of steel-frame buildings with infill masonry walls in the 1906 San Francisco earthquake. Earthquake Spectra, 22(1), 43-67. doi:10.1193/1.2185656

Haselton, C.B., Goulet, C.A., Mitrani-Reiser, J., Beck, J.L., Deierlein, G.G., Porter, K.A., (2007). An assessment to benchmark the seismic performance of a code-conforming reinforced concrete momentframe building (No. PEER 2007/12).

Haselton, C. B., Liel, A. B., Lange, S. T., \& Deierlein, G. G. (2008). Beam-column element model calibrated for predicting flexural response leading to global collapse of RC frame buildings (No. PEER 2007/03). CA, Berkeley.

Hashemi, A., \& Mosalam, K. (2007). Seismic evaluation of reinforced concrete buildings including effects of masonry infill walls, PEER Technical Report. Pacific Earthquake Engineering Research Center.

Lepage, A. (1997) A Method for Drift-Control in Earthquake-Resistant Design of RC Building Structures. PhD Thesis, University of Illinois, Urbana, 251.

Matjaz, D., \& Fajfar, P. (2005). Simplified Non-linear Seismic Analysis of Infilled Reinforced Concrete Frames. Earthquake Engineering \& Structural Dynamics, 34(1), 49-66. doi:10.1002/eqe.411

Negro, P., \& Verzeletti, G. (1996). Effect of Infills on the Global Behaviour of Frames: Energy Considerations from Pseudo-dynamic Tests. Earthquake Engineering \& Structural Dynamics, 25(8), 753-773. doi:10.1002/(SICI)1096-9845(199608)25:8<753::AID-EQE578>3.0.CO;2-Q

Park, Y. J., Reinhorn, A. M., \& Kunnath, S. K. (1987). IDARC: Inelastic Damage Analysis of Reinforced Concrete Frame - Shear-Wall Structures. Technical Report NCEER-87-0008, State University of New York at Buffalo.

Rodriguez, M. E. (2008) Selecting Earthquake Records for Nonlinear Dynamic Analysis of Structures, Proc Seismic Engineering International Conference Commemorating the 1908 Messina and Reggio Calabria Earthquake. doi:10.1063/1.2963824

Saneinejad, A., \& Hobbs, B. (1995). Inelastic Design of Infilled Frames. Journal of Structural Engineering, 121(4), 634-650. doi:10.1061/(ASCE)0733-9445(1995)121:4(634)

Wood, S. (1991). Performance of Reinforced Concrete Buildings Duringthe 1985 Chile Earthquake: Implications for the Design of Structural Walls. Earthquake Spectra, 7(4), 607-639. doi:10.1193/1.1585645

Zarnic, R., Gosti, S., Crewe, A. J., \& Taylor, C. A. (2001). Shaking Table Tests of 1:4 Reduced-Scale Models of Masonry Infilled Reinforced Concrete Frame Buildings. Earthquake Engineering \& Structural Dynamics, 30(6), 819-834. doi:10.1002/eqe.39 


\section{KEY TERMS AND DEFINITIONS}

Computer Simulation: Simulation run on a computer to reproduce behavior of a system.

Discrete Element Method: Is any of a family of numerical methods for computing the motion and effect of a large number of small particles.

Infill Wall: A panel that is built in between the beam and column components of the primary structural frame of a building.

Loads: Forces which are applied to a structure.

Masonry: Construction material composed of individual units laid in and bound together with or without mortar.

Steel Frame: Is a building technique which includes vertical steel columns and horizontal beams, constructed in a rectangular grid to support the floors, roof and walls of a building which are all attached to the frame.

Stiffness: Refers to the rigidity of a structural element and the extent to which it resists deformation with the application of external load. 


\section{APPENDIX: LIST OF SYMBOLS AND ACRONYMS}

$\delta:$ Interface displacement vector.

$\sigma:$ Joint normal stress.

$\tau$ : Joint shear stress.

$\nu=$ Poisson's ratio.

$\phi=$ Internal friction angle.

$\psi_{j}=$ Dilatancy angle.

c: Cohesion strength.

$\mathrm{c}_{\mathrm{u}}$ : Cohesion, ultimate value bond shear strength.

$\mathrm{E}_{\mathrm{b}}$ : Block Young's modulus.

$\mathrm{E}_{\mathrm{m}}$ : Mortar Young's modulus.

$\mathrm{E}_{\text {wall }}$ : Wall Young's modulus.

$\mathrm{E}_{\mathrm{s}}$ : Stone unit Young's modulus.

$\mathrm{f}_{\mathrm{b}}$ ': Block compressive strength.

$\mathrm{f}_{\mathrm{c}}$ ': Concrete compressive strength.

$\mathrm{f}_{\mathrm{t}}$ : Tensile strength.

$G_{f}^{I}$ : Mode-I fracture energy for tensile fracture.

$G_{f}^{I I}:$ Mode-II fracture energy for shear fracture.

$\mathrm{G}_{\mathrm{b}}$ : Block shear modulus.

$\mathrm{G}_{\mathrm{m}}$ : Mortar shear modulus.

$\mathrm{h}_{\mathrm{b}}$ : Block height.

$\mathrm{h}_{\mathrm{m}}$ : Mortar thickness.

$\mathrm{h}_{\mathrm{s}}$ : Stone unit height.

K: Joint stiffness vector.

$\mathrm{k}$ : Axial stiffness of masonry prism.

$\mathrm{k}_{\mathrm{n}}$ : Joint normal stiffness.

$\mathrm{k}_{\mathrm{s}}$ : Joint shear stiffness.

t: Interface stress vector.

$\mathrm{u}$ : Relative displacement at normal to interface.

$\mathrm{u}_{\mathrm{p}}$ : Crack opening.

v: Relative shear displacement at interface.

$\mathrm{v}_{\mathrm{p}}$ : Crack slip.

CC: Corner Crushing failure mode.

CFF: Column Flexural Failure mode.

CSF: Column Shear Failure mode.

DDA: Discontinuous Deformation Analysis.

DEM: Discrete/Distinct Element Method.

DTC: Diagonal Tension Cracking.

FEM: Finite Element Method.

HSS: Horizontal Sliding Shear failure mode.

UDEC: Universal Distinct Element Code. 